\title{
The Dynamics of Performance Volatility and Firm Valuation
}

\author{
Jianxin Daniel Chi and Xunhua Su*
}

\begin{abstract}
We construct a model to illustrate the dynamics of cash-flow volatility (CFV) and firm valuation. As a firm progressively invests in its growth opportunities, its book value increases and catches up with its market value, reducing the valuation multiple (Q). CFV decreases because of the diversification effect of investing in more market segments. We document a positive CFV-Q association, which varies with firm size, investment opportunities, and the correlation across market segments. Empirical findings strongly support the model's predictions and are robust to alternative explanations offered by extant studies on firm growth, volatility, and valuation.
\end{abstract}

\section{Introduction}

It is a well-documented empirical regularity that younger and smaller firms have more volatile performance and higher valuation, and that as firms grow older and larger, both volatility and valuation decrease. This regularity seems obvious in Figure 1, in which a large sample of U.S. firms exhibit decreasing cash-flow volatility (CFV) and decreasing valuation (Tobin's Q) in firm size. ${ }^{1}$ What is less

\footnotetext{
*Chi (corresponding author), daniel.chi@unlv.edu, Department of Finance, Lee Business School, University of Nevada, Las Vegas; Su (corresponding author), xunhua.su@nhh.no, Department of Finance, Norwegian School of Economics. We are very grateful to David Mauer (the referee), whose comments and suggestions significantly improved this paper. We also thank Ferhat Akbas, Emmanuel Alanis, Will Armstrong, Seungho Baek, Kathleen Bentley, Casten Bienz, Fredrik Carlsen, Henry Chang, Saeyoung Chang, Jeff Coles, Sena Durguner, B. Espen Eckbo, Jarrad Harford (the editor), Jørgen Haug, Tyler Hull, Thore Johnsen, Shane Johnson, Kathy Kahle, Sami Keskek, Michael Kisser, Scott Lee, Jøril Mæland, Ted Moorman, Svein-Arne Persson, Francisco Santos, Cornelius Schmidt, Mike Sullivan, Karin Thorburn, Kyle Tippens, Kangzhen Xie, Brian Young, Jianfeng Yu, Andrew Zhang; seminar participants at Arizona State University, Norwegian School of Economics, Norwegian University of Science and Technology, and University of Nevada, Las Vegas; participants at the Eastern Finance Association meeting, Financial Management Association meeting, and International Conference on Financial Risk and Corporate Finance Management; and especially Julie Wu for helpful comments and discussions. Chi gratefully acknowledges support from the National Natural Science Foundation of China (Grant Number 71172136) and summer research grant from Lee Business School at UNLV. Part of the paper was done during Su's visit at the University of Pennsylvania, kindly sponsored by Franklin Allen, and during Su's stay at Norwegian University of Science and Technology.

${ }^{1}$ Although not shown in the figure, there is a similar pattern of decreasing CFV and Q in firm age.
} 


\section{Journal of Financial and Quantitative Analysis}

\section{FIGURE 1}

\section{CFV, Q, and Asset Size}

Graphs A and B of Figure 1 plot average CFV and Q over 20 book-assets quantiles. Graph C plots average $Q$ over $20 \mathrm{CFV}$ quantiles. When forming the 20 book-assets quantiles, we first use the Consumer Price Index (CPI) to adjust book assets into constant dollar value. CFV is the standard deviation of 20 quarters of operating-cash-flow-to-assets ratio. $Q$ is market value of assets to book value of assets. The sample consists of Center for Research in Security Prices (CRSP)/Compustat firms from 1991 to 2012.
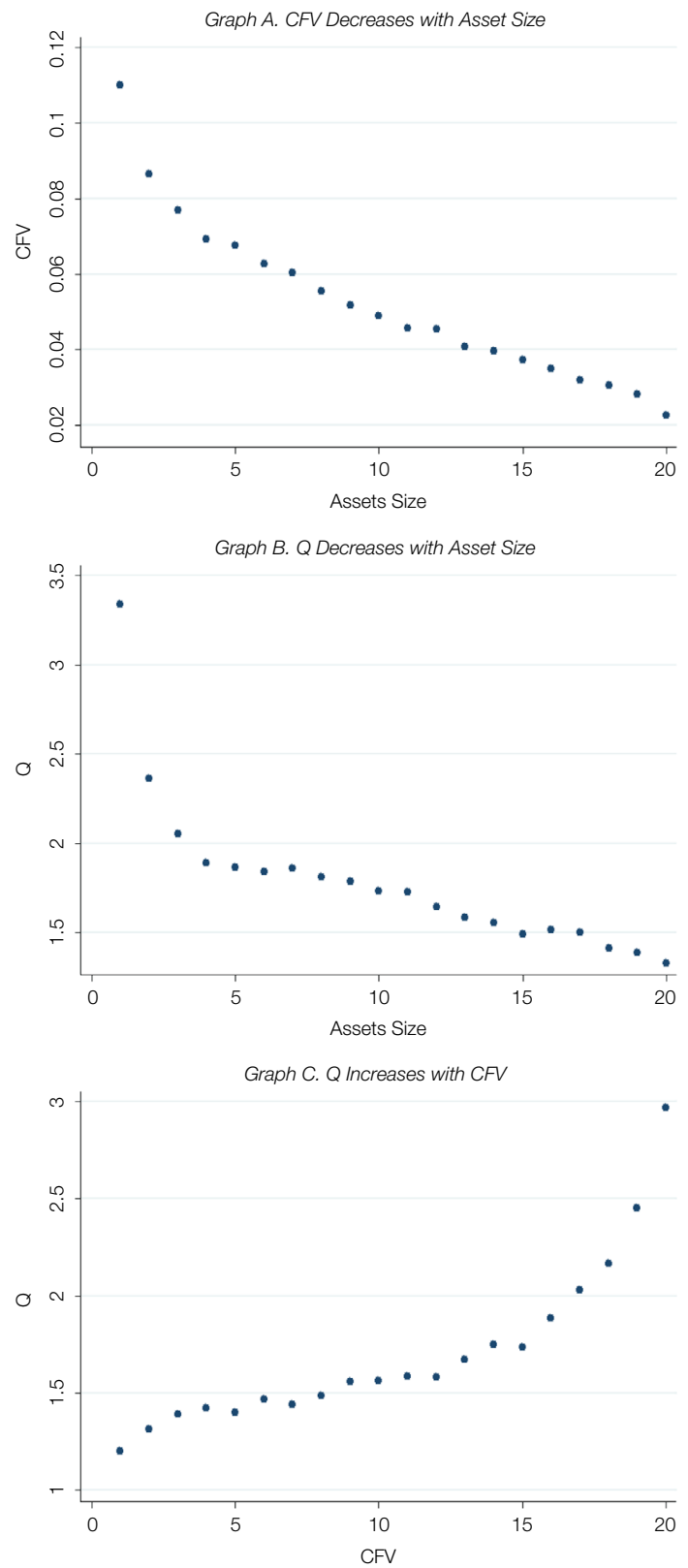
obvious, however, is why higher CFV seems to be associated with higher, rather than lower, Q (Graph C in Figure 1). After all, should not more volatile performance generally indicate higher risk and therefore be associated with lower valuation? For example, Froot, Scharfstein, and Stein (1993) argue that if external financing is constrained, volatile cash flows may hinder a firm's ability to readily capture positive net present value (NPV) projects, and its firm valuation will be diminished. Rountree, Weston, and Allayannis (2008) provide empirical evidence of a negative $\mathrm{CFV}-\mathrm{Q}$ association.

In contrast, several other theories imply a positive CFV-Q relation. First, in real-options models, a more volatile future payoff raises the value of waiting to invest if investment is irreversible (e.g., McDonald and Siegel (1986), Dixit and Pindyck (1994)). Thus, the value of real options could lead to a positive CFV-Q relation. Second, option-pricing theory suggests that higher performance volatility increases the value of equity for a levered firm (Merton (1974)). If equity value is positively correlated with firm value, the leverage effect could lead to a positive CFV-Q relation. Third, Pástor and Veronesi (2003) show that uncertainty about a firm's profitability can increase firm valuation. As the market learns about a firm over time, both uncertainty and firm valuation decrease. This implies a positive CFV-Q association insofar as volatility is positively correlated with uncertainty.

Although these studies provide insight into volatility and firm valuation, they offer opposite implications on the volatility-valuation relation. Moreover, they do not directly model the dynamics of volatility and firm valuation. Our study attempts to fill this gap in the extant literature. We develop a simple model to illustrate the dynamics of $\mathrm{CFV}$ and firm valuation as a firm grows. In particular, we explain why smaller and younger firms have higher volatility and higher valuation, and why as firms grow, both volatility and valuation decrease, resulting in a positive association between $\mathrm{CFV}$ and $\mathrm{Q}$.

The intuition of our model is straightforward. Consider a firm that can eventually grow into $N$ product or geographical market segments. Growth is not instantaneous but rather takes time. In each period, the firm is able to invest and occupy only one new market segment. After investment, each segment generates a stochastic cash flow in every subsequent period, and cash flows across segments are not perfectly correlated. With such a setting, the firm's book value reflects its assets in place, but the market value reflects both assets in place and future growth opportunities. When the firm is young and many of its opportunities have yet to receive investments, its market value is much higher than its book value, resulting in a high valuation multiple (Q). As the firm grows and invests in those opportunities, book value increases at a faster pace than market value, and Q decreases. ${ }^{2}$ During this process, CFV also decreases because cash flows are diversified across progressively more segments. The simultaneous decrease in CFV and Q as the firm grows leads to a positive CFV-Q association, which varies with firm age (size), growth opportunities, and the correlation of cash flows across market segments. Specifically, in early stages of firm growth when firm size is small and investment opportunities are large, the incremental effect of firm growth on $\mathrm{Q}$ is larger

\footnotetext{
${ }^{2}$ It is straightforward to show that other valuation metrics, such as the price-to-earnings ratio or the price-to-sales ratio, will exhibit a similar decrease as the firm grows.
} 
relative to that on $\mathrm{CFV}$, so the positive $\mathrm{CFV}-\mathrm{Q}$ association is more pronounced when the firm is young (small) and has more investment opportunities. Moreover, a higher correlation of cash flows across market segments reduces the diversification effect of investing in more segments, slowing down the incremental reduction of CFV over time, but the reduction in Q over time is not affected. Therefore, the CFV-Q association (i.e., the change in Q relative to the change in $\mathrm{CFV}$ ) is more significant when the cash-flow correlation across segments is higher.

We test the model's predictions using a large sample of U.S. firms from 1991 to 2012 and obtain three main results. First, CFV and Q decrease in firm age and size. On average, Q drops $0.14 \%$ as firm size increases by $1 \%$, and drops $0.09 \%$ as firm age increases by $1 \%$. The drop in Q slows down as a firm grows larger and older. CFV drops by a similar magnitude in firm size and age, and exhibits similar convexity. Second, we document a positive CFV-Q association. On average, Q increases $0.08 \%$ when CFV increases by $1 \%$. But for small and young firms, the increase in $\mathrm{Q}$ is almost twice as large as the increase for larger and older firms. For firms with higher growth opportunities, the increase in Q is also much larger. Third, we find that when the correlation of cash flows across market segments is higher, the positive $\mathrm{CFV}-\mathrm{Q}$ association is more pronounced. We use the number of business segments, reported in Compustat segment files, as proxy for the internal correlation of cash flows. The correlation decreases as the number of business segments increases. We find that the positive $\mathrm{CFV}-\mathrm{Q}$ relation is more pronounced for firms with a single business segment and becomes less significant as the number of business segments increases. Our empirical analysis is mostly based on firm fixed effects specifications because our model illustrates the time-series properties of CFV and Q. The findings are robust to pooled ordinary least squares (OLS) and cross-sectional Fama-MacBeth (1973) specifications. In sum, empirical evidence strongly supports our model's predictions.

Finance research has long tried to understand how firm valuation changes with volatility and through a firm's life stages. Contributing to the literature, we provide a theoretical framework that demonstrates the dynamics of CFV and firm valuation. Distinct from previous studies, our model does not require the existence of investment irreversibility in real-options models (McDonald and Siegel (1986), Dixit and Pindyck (1994)), financial leverage in option-pricing models (Merton (1974), Johnson (2004)), uncertainty in learning models (Pástor and Veronesi (2003)), or financial constraints in risk-management models (Froot et al. (1993)). Instead, our model relies on two simple and plausible assumptions: First, it takes time for a firm to undertake growth opportunities; second, cash flows are imperfectly correlated between different market segments. The first assumption guarantees the existence of growth periods and delivers the decreasing valuation result over a firm's life. The second assumption delivers the decreasing CFV result over a firm's life. Combining the two assumptions leads to a positive CFV-Q association. Also distinct from previous studies, an important insight from our model is that for the most part, the empirically observed CFV-Q association is not causal, but rather a by-product of firm growth over a firm's life cycle.

We perform various robustness checks to ensure that the empirically observed positive CFV-Q association is not driven by alternative explanations, such as mechanisms through real options, financial leverage, or uncertainty and 
learning. First, in real-options models, payoff volatility increases firm value if investments are irreversible (McDonald and Siegel (1986), Dixit and Pindyck (1994)) and if competition is not too intense to erode the value of waiting to invest (e.g., Mauer and Ott (1995), (2000), Back and Paulsen (2009), Morellec and Schürhoff (2011), and Li and Mauer (2016)). Therefore, if the positive CFV-Q association is driven by the real-options effect, it should be more pronounced for firms with more irreversible investments and less intense competition. To examine these predictions, we run the CFV-Q regression on subsamples with varying degrees of investment irreversibility and product market competition. Following the empirical literature of real options (e.g., Panousi and Papanikolaou (2012), Badertscher, Shroff, and White (2013)), we identify 6 proxies for irreversibility: firm industry stock beta; ratio of firm idiosyncratic stock return variance to total variance; industry ratio of new capital goods to total capital goods; industry average depreciation rate; industry average ratio of sales of property, plant, and equipment (PPE) to total capital; and industry liquidity ratio. We use two proxies for competition, the Herfindahl-Hirschman Index (HHI) and product market fluidity from Hoberg, Phillips, and Prabhala (2014). The CFV-Q association does not exhibit consistent differences across the subsamples formed on the 6 irreversibility measures or the two competition measures, indicating that our findings are not driven by the real-options effect.

Second, for a financially levered firm, higher volatility in the value of firm assets increases the value of firm equity, which is a call option on the underlying assets (Merton (1974)). This leverage effect may imply a positive CFV-Q association, but only for financially levered firms. However, we find that the positive CFV-Q association is large and significant even for firms with zero leverage. Thus, the leverage effect does not explain the positive CFV-Q association.

Third, the uncertainty-and-learning mechanism in Pástor and Veronesi (2003) can also lead to a positive CFV-Q relation, but this mechanism should mostly affect firms with high uncertainty. We measure uncertainty by analyst earnings forecast dispersion (e.g., Imhoff and Lobo (1992), Johnson (2004), and Zhang (2006)). We find that the CFV-Q association is even slightly stronger for firms with low analyst forecast dispersion, inconsistent with the uncertainty-andlearning effect.

Froot et al. (1993) show that volatile cash flows can force a firm to forgo positive NPV projects when external financing is constrained and therefore reduce firm value. Rountree et al. (2008) provide empirical evidence of a negative CFV-Q association. However, we find that the negative CFV-Q association documented by Rountree et al. reverses to positive once we standardize their CFV measure to make it comparable across firms. In a nutshell, their paper relates $Q$ to per share CFV. There is a mechanical negative relation between $\mathrm{Q}$ and per share $\mathrm{CFV}$ because larger firms on average have lower $\mathrm{Q}$, larger per share size, and thus larger per share CFV. When per share cash flow is properly scaled to account for differences in per share size, the relation between $\mathrm{Q}$ and CFV becomes positive. ${ }^{3}$

\footnotetext{
${ }^{3}$ For example, Berkshire Hathaway has the largest per share cash-flow standard deviation in our sample mostly because Berkshire Hathaway has by far the largest per share size, but it does not mean that Berkshire Hathaway has the highest CFV or risk, nor should one relate per share CFV to firm Q. The sensible way to compare CFV across firms and to examine the relation between CFV and firm
} 
Our findings do not mean that the positive CFV-Q association cannot be partly attributed to the real-options effect, the leverage effect, or the uncertaintyand-learning effect. Rather, with very simple assumptions, our model illustrates an alternative economic mechanism and provides a rational explanation to the empirically observed positive CFV-Q association. Risk management that reduces CFV could very well enhance firm valuation, though this effect does not outweigh the positive CFV-Q association observed in the data. ${ }^{4}$

Our work is also related to firm life-cycle studies (e.g., Spence (1977), (1979), Gort and Klepper (1982)). These studies focus on the relation between life-cycle stages and performance variables such as revenue, earnings, and dividend payout (e.g., Dickinson (2011), Warusawitharana (2014)), and do not say much about performance volatility or firm valuation, or the association between volatility and valuation, which are the focus of our study. An alternative explanation to decreasing $\mathrm{Q}$ in firm age and size is decreasing return to scale; for example, as a firm's asset size increases, the marginal return on assets (ROA) decreases, causing Q to decrease. However, we find that in our sample larger or older firms on average have higher, rather than lower, ROA, even after considering the survival effect. This suggests that decreasing return to scale does not explain the dynamics of firm valuation.

Finally, there is extensive literature examining the relation between Tobin's Q (or firm valuation) and firm characteristics such as ownership structure (Demsetz and Lehn (1985)), diversification (Lang and Stulz (1994)), governance (Gompers, Ishii, and Metrick (2003)), corporate cash holdings (Harford, Mansi, and Maxwell (2008)), and capital and priority structure (Hackbarth and Mauer (2012)). Adding to this literature, we develop a simple theory and provide empirical evidence of a positive relation between firm performance volatility and Q.

\section{CFV and Firm Valuation: An Illustrative Model}

\section{A. Basic Setup}

We consider a business firm with $N$ product market segments, which can be thought of as segments with different geographical locations or for vertically different products. There are infinite periods, $1,2,3, \ldots$. To occupy a market segment, the firm has to undertake an initial investment, $I$, which will generate a stochastic cash flow in every following period. These cash flows are normally distributed with mean $\mu$ and variance $\sigma^{2}$, and are independent across periods but dependent with correlation $\rho(0 \leq \rho<1)$ across segments within a period. Denote the

\footnotetext{
$\mathrm{Q}$ is to first scale cash flow by some common denominator, such as book assets, and then compare volatility in the cash-flow-to-assets ratio.

${ }^{4}$ Empirical evidence on risk management and firm valuation is mixed. Allayannis and Weston (2001) show that the use of foreign exchange derivatives increases firm value by $5 \%$ for their sample firms. However, Guay and Kothari (2003) argue that the claimed effect of derivative hedging on firm valuation is implausibly large. Jin and Jorion (2006) find no relation between hedging and firm value in a sample of oil and gas producers that should benefit greatly from hedging. Adam, Dasgupta, and Titman (2007) examine a firm's hedging decision and suggest that even financially constrained firms can have an incentive not to hedge.
} 
discount rate of the economy as $\beta$, which is smaller than but close to 1 . Suppose that the expected NPV of each market segment is positive, that is, $\beta \mu /(1-\beta)>I$.

We assume that investments or growth are time consuming. Specifically, the firm is able to invest in and occupy at most one market segment in each period. Namely, the firm needs at least $N$ periods to occupy all market segments. In practice, firms need time to build up new products, factories, and equipments, as well as intangible assets such as patents and reputation, to train new personnel and to occupy more geographical or product markets (e.g., Spence (1979)). This assumption guarantees the existence of the growth periods of the firm, defined as those during which the firm expands its investments to more market segments. One can think of the growth periods as the growth phase in the firm's life cycle. Moreover, for convenience, we assume that there are no further investments after the initial investment in each market segment and that the firm pays out all realized cash flows as dividends.

The positive NPV of investing in every segment incentivizes the firm to take all market segments. Given $\beta<1$, optimally the firm will continue to invest in one segment in each of the first $N$ periods. Therefore, the growth periods of the firm in our model consist of the first $N$ periods. After period $N$, investments have completed in all market segments, and the firm has no future growth opportunities. As the firm enters its maturity phase, its value and expected cash flows will stay constant over time, so there is no correlation between firm size, cash flows, and firm valuation. Henceforth, our theoretical analysis focuses on the growth periods to show the dynamics of performance volatility and firm valuation.

\section{B. The Dynamics of CFV and Firm Valuation}

We now consider the firm's $\mathrm{CFV}$ and firm valuation during its growth periods. In period $t(t \leq N)$, book value of the firm, also called firm size, is $B_{t}=t \times I$. This firm size is growing linearly over time. The firm's total cash flow, $x_{t}$, comes from the $t$ market segments occupied in the first $t$ periods. We define CFV of the firm in period $t$ as the standard deviation of $x_{t} / B_{t}$, which is

$$
\sigma_{t}=\frac{\sigma}{I} \times \sqrt{\rho+(1-\rho) \times \frac{1}{t}} .
$$

CFV decreases over time due to the diversification effect of investing in more market segments, but increases with $\rho$ because higher correlation across segments reduces this diversification effect. Namely,

$$
\begin{aligned}
\frac{\partial \sigma_{t}}{\partial t} & =-\frac{1}{2} \times \frac{\sigma}{I} \times \frac{1}{t^{2}} \times \frac{1-\rho}{\sqrt{\rho+(1-\rho) / t}}<0, \\
\frac{\partial \sigma_{t}}{\partial \rho} & =\frac{1}{2} \times \frac{\sigma}{I} \times \frac{1-1 / t}{\sqrt{\rho+(1-\rho) / t}}>0 .
\end{aligned}
$$

In our setting, firm book value, $B_{t}$, is a linear function of $t$, so $B_{t}$ is also a proxy for firm growth. Because CFV decreases in $t$ and $B_{t}$ during the growth periods, we say that $\mathrm{CFV}$ decreases in firm growth. However, when the firm grows, the incremental effect of diversification on CFV diminishes. This can be seen from the fact that $\sigma_{t}$ is a decreasing and convex function of $t$, that is, $\partial \sigma_{t} / \partial t<0$ and $\partial^{2} \sigma_{t} / \partial t^{2}>0$. 
Firm market value in period $t(t \leq N)$ is the sum of discounted future cash flows in all market segments. It consists of two parts. First, each of the $t$ occupied market segments has a market value, $\beta \mu /(1-\beta)$. Second, the $N-t$ unoccupied segments, respectively, have market values,

$$
\frac{\beta^{2} \mu}{1-\beta}, \quad \frac{\beta^{3} \mu}{1-\beta}, \ldots, \frac{\beta^{N-t+1} \mu}{1-\beta} .
$$

In total, firm market value in period $t$ is

$$
V_{t}=\left[t+\frac{\beta\left(1-\beta^{N-t}\right)}{1-\beta}\right] \times \frac{\beta}{1-\beta} \times \mu .
$$

The market-to-book ratio, or $\mathrm{Q}$, in period $t$ is thus

$$
q_{t}=\frac{V_{t}}{B_{t}}=\left[1+\frac{\beta}{1-\beta} \times \frac{1-\beta^{N-t}}{t}\right] \times \frac{\beta}{1-\beta} \times \frac{\mu}{I}
$$

and

(6) $\frac{\partial q_{t}}{\partial t}=-\frac{1}{t^{2}} \times\left(\frac{\beta}{1-\beta}\right)^{2} \times \frac{\mu}{I} \times\left[1-\beta^{N-t}-\beta^{N-t} \times \ln \beta\right]<0$;

that is, the market-to-book ratio, or Q, decreases as the firm grows. Intuitively, when more investments have been undertaken over time, book value increases at a faster pace than market value, reducing the market-to-book ratio. This is because book value reflects only assets in place whereas market value reflects both assets in place and future growth opportunities. As the firm grows, fewer opportunities are left and book value catches up with market value. This coincides with the real-world observation that, in general, firm market-to-book ratio is negatively correlated with firm age and size. ${ }^{5}$ Furthermore, given that $\beta$ is smaller than but close to 1 , we have

$$
\text { (7) } \begin{aligned}
\frac{\partial^{2} q_{t}}{\partial t^{2}} & =\frac{2}{t^{3}} \times\left(\frac{\beta}{1-\beta}\right)^{2} \times \frac{\mu}{I} \times\left[1-\beta^{N-t} \times(1+\ln \beta)\left(1-\frac{t}{2} \times \ln \beta\right)\right] \\
& >\frac{2}{t^{3}} \times\left(\frac{\beta}{1-\beta}\right)^{2} \times \frac{\mu}{I} \times\left[1-\beta^{N-t}\right]>0 .
\end{aligned}
$$

Therefore, $q_{t}$ is a convex function of $t$. As the firm grows, the incremental effect of firm age or size on $\mathrm{Q}$ decreases.

The dynamics of firm CFV and Q shown in our model are consistent with Figure 1, in which both CFV and Q are roughly convex functions of firm size. More rigorous tests on this convexity are conducted in Section IV.

\footnotetext{
${ }^{5}$ Although firm valuation is measured by $\mathrm{Q}$ in our analysis, it is straightforward to show that other popular valuation metrics, such as the price-to-cash-flow ratio, price-to-earnings ratio, or price-to-sales ratio, exhibit a similar pattern.
} 


\section{The CFV-Q Association}

As we show earlier, both CFV and Q decrease in firm growth, implying a positive CFV-Q association during the growth periods of the firm. Mathematically, this positive association can be seen from

$$
\begin{aligned}
\frac{\partial q_{t}}{\partial \sigma_{t}}= & \frac{2 \mu}{\sigma} \times\left(\frac{\beta}{1-\beta}\right)^{2} \times \frac{\sqrt{\rho+(1-\rho) / t}}{1-\rho} \\
& \times\left[1-\beta^{N-t}-\ln \beta \times \beta^{N-t}\right]>0 .
\end{aligned}
$$

When discount factor $\beta$ is close to 1 , which is mostly the case in practice, $1+\ln \beta>0$. From equation (8), we have

$$
\begin{aligned}
\frac{\partial^{2} q_{t}}{\partial \sigma_{t} \partial t}= & \frac{\mu}{\sigma} \times\left(\frac{\beta}{1-\beta}\right)^{2} \\
& \times\left[\frac{2}{1-\rho} \times \sqrt{\rho+(1-\rho) / t} \times \beta^{N-t} \ln \beta \times(1+\ln \beta)\right. \\
& \left.-\frac{1}{t^{2}} \frac{1}{\sqrt{\rho+(1-\rho) / t}} \times\left(1-\beta^{N-t}-\ln \beta \times \beta^{N-t}\right)\right]<0 .
\end{aligned}
$$

The positive CFV-Q association is more significant for firms in their early growth periods, that is, those with younger age or smaller size, and becomes less significant as firms grow into their later growth periods. To get this result, note that when a firm diversifies into the $t$ th segment, its CFV decreases by $t^{-\frac{1}{2}}$, but Q decreases approximately by $t^{-1}$. Roughly a 1 -unit change in CFV is associated with $t^{-\frac{1}{2}}$ units of change of Q. Therefore, the CFV-Q association becomes less significant as the firm grows.

Furthermore, the correlation of cash flows, $\rho$, reduces the diversification effect of investing in more market segments, so it directly affects CFV and indirectly affects the CFV-Q association. We can see this from

$$
\begin{aligned}
\frac{\partial^{2} q_{t}}{\partial \sigma_{t} \partial \rho}= & \frac{2 \mu}{\sigma} \times\left(\frac{\beta}{1-\beta}\right)^{2} \times\left[1-\beta^{N-t}-\ln \beta \times \beta^{N-t}\right] \\
& \times \frac{1+\rho+(1-\rho) / t}{2(1-\rho)^{2} \times \sqrt{\rho+(1-\rho) / t}}>0 .
\end{aligned}
$$

The positive CFV-Q association is larger for higher $\rho$. Intuitively, the reduction in CFV over time is slowed down for higher $\rho$, but the reduction in Q over time is not affected, resulting in a larger $\partial q / \partial \sigma$.

So far, we have assumed that there are no further investments after the initial investment in each segment and that the firm pays out all realized cash flows as dividends. These two assumptions are for modeling parsimony and do not drive the positive association between CFV and Q. First, recall that the key driver of the positive CFV-Q association is that both $\mathrm{CFV}$ and $\mathrm{Q}$ decrease as the firm grows. CFV decreases over time because of the diversification effect of investing in more market segments. Q decreases because book value increases faster than market value as the firm grows: Book value reflects only assets in place, but market value already reflects discounted future cash flows from all market segments, even the 
segments that have not been invested in. Logically, as long as both CFV and Q are decreasing as the firm grows, the positive CFV-Q association obtains. Notice that even if the firm retains all or some of the realized cash flows or makes additional investment in a market segment, both its CFV and Q are still decreasing as the firm grows, so the positive CFV-Q association holds. Therefore, relaxing the two original assumptions that the firm makes no additional investment in each segment and pays out all cash flows as dividends does not change the model's predictions.

\section{Testable Hypotheses and Empirical Design}

\section{A. Testable Hypotheses}

Based on the model, we form the following testable hypotheses. Our first hypothesis comes from the fact that both $\sigma_{t}$ and $q_{t}$ are decreasing and convex in $t$.

Hypothesis 1. Firm CFV and Q both decrease in firm growth, measured by firm age and size (book assets). These effects of firm growth decrease as firms grow.

Our model mainly shows the time-series properties of firm growth, so empirically we expect that firm growth, as measured by firm age or size, has a significant within-firm effect on CFV and Q. These predictions would also be valid in the cross section if firms are homogeneous. However, empirically firms are heterogeneous, and probably a significant part of the heterogeneity is unobservable. We thus base our empirical interpretation mostly on firm fixed effects specifications, and implement cross-sectional tests as robustness checks.

Because both CFV and Q decrease as a firm grows, they are positively associated as equation (8) shows, although such a positive association does not mean a causal effect. Also from equation (9), we see that the CFV-Q association is more significant for firms in their early growth periods. We thus form our second hypothesis.

Hypothesis 2. CFV is positively associated with $\mathrm{Q}$, and the $\mathrm{CFV}-\mathrm{Q}$ association is more pronounced for younger and smaller firms.

As a firm in its early stages of growth has larger investment opportunities, the positive association between CFV and Q should be more pronounced for firms with larger investment opportunities. This is the third hypothesis.

Hypothesis 3. The positive association between CFV and Q is more pronounced for firms with larger investment opportunities.

Our last hypothesis is about the correlation of firm cash flows across market segments, $\rho . \rho$ affects the diversification effect of investing in more market segments, so it directly affects CFV and indirectly affects the CFV-Q association. From equation (10), the positive CFV-Q association is larger for higher $\rho$.

Hypothesis 4. The positive association between CFV and Q is more pronounced for firms with higher correlation of cash flows across market segments.

In the next section, we design within- and cross-firm tests to examine the model's predictions. 


\section{B. Empirical Methodology}

To test Hypothesis 1, we mainly employ firm fixed effects specifications as follows:

$$
\begin{aligned}
\ln \left(\mathrm{CFV}_{i t}\right) & =\alpha+\beta \times \text { FIRM_GROWTH }_{i t}+\Gamma X_{i t}+\theta_{i}+\phi_{t}+\epsilon_{i t}, \\
\ln \left(\mathrm{Q}_{i t}\right) & =\alpha+\beta \times \text { FIRM_GROWTH }_{i t}+\Gamma X_{i t}+\theta_{i}+\phi_{t}+\epsilon_{i t},
\end{aligned}
$$

where $\ln (\mathrm{CFV})$ and $\ln (\mathrm{Q})$ are the natural logarithm of $\mathrm{CFV}$ and the natural logarithm of Q, respectively. FIRM_GROWTH is proxied by firm age and size (book assets CPI-adjusted to the 2004 dollar). $X$ are control variables, $\theta$ is firm fixed effects, and $\phi$ is year fixed effects. The theoretical definitions of CFV and Q are in equations (1) and (5) above. Empirically, we measure CFV as the standard deviation of the operating-cash-flow-to-assets ratio in past 20 quarters, and Q as the market-to-book ratio. We take the log value of both to reduce their positive skewness. The control variables include profitability, financial leverage, assets tangibility, cash holdings, sales growth in the past 5 years, research and development $(R \& D)$ capital, capital expenditures, and a dividend dummy. R\&D capital is defined as the sum of R\&D-to-sales ratios in the past 5 years, using a $20 \%$ depreciation rate (e.g., Chan, Lakonishok, and Sougiannis (2001)). All these variables are plausibly correlated with Q and CFV, and therefore should be controlled for in our tests. Our model predicts that $\beta$ in models (11) and (12) are negative.

To test Hypothesis 2, we specify the following models:

$$
\begin{aligned}
\ln \left(\mathrm{Q}_{i t}\right)= & \alpha+\gamma_{1} \times \ln \left(\mathrm{CFV}_{i t}\right)+\beta \times \text { FIRM_GROWTH }_{i t} \\
& +\Gamma X_{i t}+\theta_{i}+\phi_{t}+\epsilon_{i t} \\
\ln \left(\mathrm{Q}_{i t}\right)= & \alpha+\gamma_{2} \times \ln \left(\mathrm{CFV}_{i t}\right)+\gamma_{3} \times \mathrm{SMALL}_{i t}+\gamma_{4} \times \ln \left(\mathrm{CFV}_{i t}\right) \\
& \times \mathrm{SMALL}_{i t}+\beta \times \mathrm{FIRM}_{-} \mathrm{SROWTH}_{i t}+\Gamma X_{i t}+\theta_{i}+\phi_{t}+\epsilon_{i t} .
\end{aligned}
$$

The CFV-Q association is captured by $\gamma_{1}$ in model (13). To further test whether this association is more pronounced for small (or young) firms, we include in the regression an interaction term between $\mathrm{CFV}$ and the dummy for small (or young) firms, $\ln (\mathrm{CFV}) \times \mathrm{SMALL}$ (or $\ln (\mathrm{CFV}) \times$ YOUNG), as specified in model (14). The SMALL (or YOUNG) dummy is equal to 1 if the firm's book assets (or firm age) are below the median of all firms in that year. $\gamma_{4}$ in model (14) captures the difference in the CFV-Q association between small and large firms. When replacing SMALL by YOUNG in this specification, $\gamma_{4}$ captures the difference between young and old firms. According to Hypothesis 2, both $\gamma_{1}$ in model (13) and $\gamma_{4}$ in model (14) are positive.

We replace SMALL with a dummy proxy of firm growth opportunities to test Hypothesis 3. The coefficient of the interaction term thus captures the difference in the CFV-Q association between firms with large and small growth opportunities. Our model also predicts a positive coefficient on the interaction term. As mentioned earlier, the first three hypotheses concern time-series properties of firm growth, so all the empirical models above include firm fixed effects. As a robustness check, we also run Fama and MacBeth (1973) tests to investigate the CFV-Q association cross-sectionally. 
Finally, we test Hypothesis 4 (the effect of cash-flow correlation across market segments) with the following empirical model,

$$
\begin{aligned}
\ln \left(\mathrm{Q}_{i t}\right)= & \alpha+\gamma_{2} \times \ln \left(\mathrm{CFV}_{i t}\right)+\gamma_{3} \times \mathrm{CORR}_{i t}+\gamma_{4} \times \ln \left(\mathrm{CFV}_{i t}\right) \\
& \times \mathrm{CORR}_{i t}+\Gamma X_{i t}+\phi_{t}+\epsilon_{i t} .
\end{aligned}
$$

CORR in model (15) is the proxy for the correlation of cash flows across market segments. Two proxies are used in our tests: the number of firms' business segments and a dummy for single-segment firms as identified in Compustat Business Segment files. Note that "business segments" in Compustat and market segments in our model are not conceptually the same. For example, even firms with a single business segment can have multiple market segments. We use the number of business segments from Compustat as a proxy for cash-flow correlation across the market segments in our model. Firms with fewer business segments likely have higher cash-flow correlation across market segments, and single-businesssegment firms likely have even higher cash-flow correlation across market segments. Because the number of segments for most firms does not change much over time, we expect the effect to be more visible across firms than within firm and thus rely our interpretation mainly from the Fama-MacBeth (1973) specification of model (15). We expect $\gamma_{4}$ to be negative when CORR is the number of segments and positive when CORR is the single-segment dummy.

\section{Empirical Evidence}

\section{A. Data and Sample}

We obtain firm financial data from the Center for Research in Security Prices (CRSP)/Compustat merged database. Compustat starts reporting operating cashflow data in 1987. We require 20 quarters of cash-flow data to compute CFV. Therefore, our regression data set runs from 1991 to 2012 and consists of surviving and nonsurviving firms that appear in Compustat at any time during the sample period. We exclude financial firms (Standard Industrial Classification (SIC) codes 6000-6999), regulated utility firms (SIC codes 4900-4999), and public administration entities (SIC codes 9100-9999) because these firms' cash-flow characteristics are not directly comparable with firms in other industries. We also require that a firm-year observation has positive total assets and other requisite control variables to be included in our analysis. Our final sample includes 10,714 unique firms with over 80,000 firm-year observations. To reduce the effect of extreme outliers, we winsorize all continuous regression variables at the 1st and 99th percentiles.

Detailed variable definitions are summarized in the Appendix, and summary statistics are shown in Table 1. Panel A shows summary statistics of the key variables by asset-size quartiles. As we move up through size quartiles, Q and CFV decrease, and age increases. We also observe that as firm size increases, leverage, tangibility, profitability, and dividends increase, whereas cash holdings, R\&D capital, and capital expenditures decrease. All these associations seem reasonable.

Panel B of Table 1 reports summary statistics by firm-age quartiles. For most variables, the patterns of change through age quartiles are similar to the patterns through size quartiles, confirming that size and age are positively correlated. One 
TABLE 1

\section{Summary Statistics}

Table 1 presents summary statistics and pairwise correlations for the main variables used in the tests. The variable descriptions are in the Appendix. The observations consist of surviving and nonsurviving firms that appear in Center for Research in Security Prices (CRSP)/Compustat at any time from 1991 to 2012. We exclude financial firms (Standard Industrial Classification (SIC) codes 6000-6999), utility firms (SIC codes 4900-4999), and public administration entities (SIC codes 9100-9999). The full sample includes 10,714 unique firms with 88,527 firm-year observations.

Panel A. Summary Statistics by Asset-Size Quartiles

\begin{tabular}{lrr} 
& \multicolumn{2}{c}{ Asset Size Q1 } \\
\cline { 2 - 3 } & Mean & Std. Dev. \\
\cline { 2 - 3 } Q & 2.21 & 2.42 \\
CFV & 0.07 & 0.07 \\
ASSETS & 26.38 & 21.92 \\
AGE & 13.49 & 8.95 \\
LEVERAGE & 0.49 & 0.44 \\
TANGIBILITY & 0.21 & 0.21 \\
ROA & -0.24 & 0.43 \\
CASH/ASSETS & 0.27 & 0.26 \\
SALES_GROWTH & 0.12 & 0.31 \\
RD_CAPITAL & 2.47 & 8.09 \\
CAPEX & 0.17 & 0.56 \\
DIVIDEND & 0.07 & 0.25
\end{tabular}

Asset Size Q2

\begin{tabular}{|c|c|}
\hline Mean & Std. Dev. \\
\hline 1.62 & 1.55 \\
\hline 0.05 & 0.05 \\
\hline 135 & 95 \\
\hline 14.48 & 10.06 \\
\hline 0.45 & 0.30 \\
\hline 0.25 & 0.22 \\
\hline-0.04 & 0.22 \\
\hline 0.22 & 0.23 \\
\hline 0.16 & 0.27 \\
\hline 1.04 & 4.98 \\
\hline 0.14 & 0.44 \\
\hline 018 & \\
\hline
\end{tabular}

Panel B. Summary Statistics by Firm-Age Quartiles

\begin{tabular}{lcc} 
& \multicolumn{2}{c}{ Firm Age Q1 } \\
\cline { 2 - 3 } & Mean & Std. Dev. \\
\cline { 2 - 3 } Q & 2.05 & 2.06 \\
CFV & 0.06 & 0.06 \\
ASSETS & 1,068 & 4,347 \\
AGE & 6.61 & 2.30 \\
LEVERAGE & 0.50 & 0.35 \\
TANGIBILITY & 0.26 & 0.24 \\
ROA & -0.13 & 0.36 \\
CASH/ASSETS & 0.25 & 0.25 \\
SALES_GROWTH & 0.27 & 0.35 \\
RD_CAPITAL & 1.71 & 6.55 \\
CAPEX & 0.21 & 0.57 \\
DIVIDEND & 0.13 & 0.34
\end{tabular}

Firm Age Q2

\begin{tabular}{|c|c|}
\hline \multicolumn{2}{|c|}{ Firm Age Q2 } \\
\hline Mean & Std. Dev. \\
\hline 1.76 & 1.77 \\
\hline 0.05 & 0.06 \\
\hline 1,129 & 4,140 \\
\hline 10.72 & 2.79 \\
\hline 0.52 & 0.34 \\
\hline 0.26 & 0.23 \\
\hline-0.07 & 0.29 \\
\hline 0.20 & 0.22 \\
\hline 0.17 & 0.28 \\
\hline 1.37 & 6.00 \\
\hline 0.15 & 0.44 \\
\hline 0.17 & \\
\hline
\end{tabular}

Asset Size Q3

\begin{tabular}{|c|c|}
\hline Mean & Std. Dev. \\
\hline 1.54 & 1.33 \\
\hline 0.04 & 0.04 \\
\hline 561 & 421 \\
\hline 17.24 & 12.27 \\
\hline 0.53 & 0.28 \\
\hline 0.30 & 0.23 \\
\hline 0.02 & 0.15 \\
\hline 0.15 & 0.18 \\
\hline 0.15 & 0.23 \\
\hline 0.32 & 2.28 \\
\hline 0.12 & 0.35 \\
\hline
\end{tabular}

Firm Age Q3

\begin{tabular}{|c|c|}
\hline \multicolumn{2}{|c|}{ Firm Age Q3 } \\
\hline Mean & Std. Dev. \\
\hline 1.66 & 1.66 \\
\hline 0.05 & 0.05 \\
\hline 1,846 & 6,110 \\
\hline 17.52 & 4.07 \\
\hline 0.51 & 0.33 \\
\hline 0.28 & 0.23 \\
\hline-0.03 & 0.24 \\
\hline 0.17 & 0.20 \\
\hline 0.12 & 0.22 \\
\hline 0.76 & 4.29 \\
\hline 0.11 & 0.33 \\
\hline 0.28 & 0.45 \\
\hline
\end{tabular}

Asset Size Q4

\begin{tabular}{cc}
\hline Mean & Std. Dev \\
1.44 & 1.17 \\
0.03 & 0.04 \\
7,892 & 11,426 \\
25.72 & 16.69 \\
0.61 & 0.22 \\
0.36 & 0.24 \\
0.04 & 0.10 \\
0.10 & 0.12 \\
0.14 & 0.19 \\
0.09 & 0.59 \\
0.12 & 0.27 \\
0.62 & 0.49
\end{tabular}

Firm Age Q4

\begin{tabular}{|c|c|}
\hline \multicolumn{2}{|c|}{ Firm Age Q4 } \\
\hline Mean & Std. Dev \\
\hline 1.27 & 1.00 \\
\hline 0.03 & 0.04 \\
\hline 4,739 & 9,800 \\
\hline 37.91 & 10.00 \\
\hline 0.56 & 0.26 \\
\hline 0.31 & 0.22 \\
\hline 0.03 & 0.14 \\
\hline 0.11 & 0.13 \\
\hline 0.07 & 0.14 \\
\hline 0.11 & 1.04 \\
\hline 0.08 & 0.21 \\
\hline 0.61 & 0.49 \\
\hline
\end{tabular}

(continued on next page) 
.

TABLE 1 (continued)

Summary Statistics

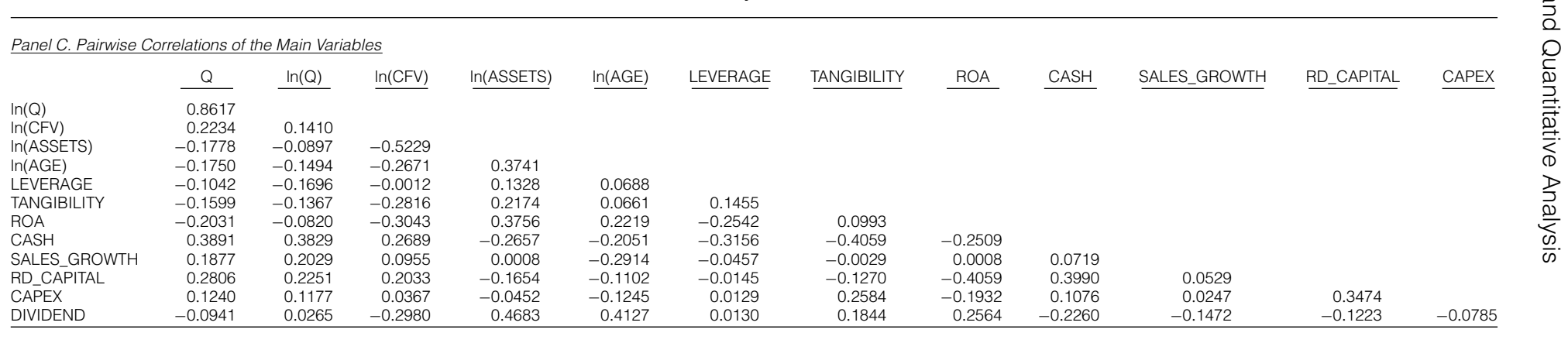


noticeable difference is sales growth, which decreases monotonically through age quartiles but is hump-shaped through size quartiles.

Panel C of Table 1 reports correlations between regression variables. An important observation, consistent with our main prediction, is that size and age are negatively correlated with $\mathrm{CFV}$ and Q, whereas CFV is positively correlated with Q. The correlation between age and size is 0.37 . Although relatively high, this correlation coefficient suggests that each variable could still capture different aspects of how far a firm has grown. We use both age and size as proxies for firm growth.

\section{B. CFV and Firm Valuation as a Firm Grows}

We start with testing Hypothesis 1 that as a firm grows, both CFV and Q decrease. The empirical implementation is outlined in models (11) and (12). In Table 2 we examine how Q changes with firm size and age. Column 1 shows the simplest OLS specification, in which we regress $\ln (\mathrm{Q})$ on size and age without any additional control. As predicted, firm valuation decreases in size and age.

As mentioned earlier, our model primarily shows the time-series properties of firm growth. Therefore, it is critical to control for firm heterogeneity because for firms with the same age and size, how far they have grown and how much more they will grow can differ greatly. Firm fixed effects go a long way in controlling for unobservable firm heterogeneity, and therefore we use a firm fixed effects specification as our main empirical methodology. When controlling for firm fixed effects in column 2 , the coefficients on size and age become larger. The within $R^{2}(4 \%)$ is also higher than the OLS $R^{2}(2 \%)$, suggesting a better fit of the firm fixed effects specification. In column 3 we control for important observable firm characteristics that are potentially correlated with both Q and size or age. The coefficient estimate on size doubles, but the coefficient on age drops, though both stay highly significant. Because the dependent variable Q and the two explanatory variables are natural logarithm values, the coefficient estimates imply that $\mathrm{Q}$ drops $0.14 \%$ as firm size increases by $1 \%$, and drops $0.09 \%$ as firm age increases by $1 \%$; both are economically large. The control variables have predicted signs that are consistent with earlier findings in the literature. For example, $\mathrm{Q}$ is negatively related to financial leverage and positively related to profitability, sales growth, and R\&D capital.

We then examine the predicted convexity between $\mathrm{Q}$ and size (age). As a firm grows, $Q$ should decrease at a decreasing rate. By using natural logarithmic transformation of key regression variables and thus reducing positive skewness, regressions in columns 1-3 to some extent already account for this convexity. To more directly identify this convexity, in column 4 we include squared terms of unlogged values of size and age. As predicted, the squared terms are positive and the unsquared terms remain negative, consistent with the predicted convexity of $\mathrm{Q}$ in size and age. However, there is a possibility that the convexity in column 4 is mechanically induced because the dependent variable $\ln (\mathrm{Q})$ is a concave transformation of Q. In column 5, we use unlogged Q as the dependent variable, and the convexity remains. The findings in Table 2 are consistent with Hypothesis 1 that firm valuation decreases as a firm grows, and the decrease exhibits a decreasing speed. 
TABLE 2

Change in Firm Valuation (Q) as Firms Grow

Table 2 reports results of firm fixed effects and pooled ordinary least squares (OLS) regressions where the dependent variable is $\ln (\mathrm{Q})$. We study how firm growth, proxied by firm size (ASSETS) and firm age (AGE), affects firm valuation. Model 1 is a pooled OLS regression without controls. Model 2 includes firm fixed effects. Models 3 and 4 add all additional controls. To capture the nonlinear effect of firm growth on $\mathrm{Q}$, models 4 and 5 add quadratic terms of assets and age. The dependent variable in model 5 is unlogged Q. For purely aesthetic reasons, in models 4 and 5 , the coefficient estimate for assets is multiplied by 10,000 , for age by 10 . An intercept is included but not reported. $R^{2}$ for firm fixed effects is the within $R^{2}$; for OLS is the adjusted $R^{2}$. Standard errors are clustered at the firm level and corrected for heteroskedasticity. Variables of interest are in bold, and $t$-values are reported in parentheses. ${ }^{*},{ }^{* *}$, and ${ }^{* * *}$ indicate significance at the $10 \%$, $5 \%$, and $1 \%$ levels, respectively.

\begin{tabular}{|c|c|c|c|c|c|}
\hline $\begin{array}{l}\text { Dependent } \\
\text { Variable }\end{array}$ & $\begin{array}{c}\text { OLS } \\
\ln (Q) \\
1\end{array}$ & $\begin{array}{c}\text { Firm } \\
\text { Fixed Effects } \\
\text { In(Q) } \\
2\end{array}$ & $\begin{array}{c}\text { Firm } \\
\text { Fixed Effects } \\
\text { In(Q) } \\
3\end{array}$ & $\begin{array}{c}\text { Firm } \\
\text { Fixed Effects } \\
\text { In(Q) } \\
4\end{array}$ & $\begin{array}{c}\text { Firm } \\
\text { Fixed Effects } \\
Q \\
5\end{array}$ \\
\hline In(ASSETS) & $\begin{array}{l}-0.01^{\star \star \star} \\
(-4.06)\end{array}$ & $\begin{array}{l}-0.07^{\star \star \star} \\
(-9.78)\end{array}$ & 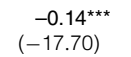 & & \\
\hline $\ln (A G E)$ & $\begin{array}{l}-0.14^{\star \star \star} \\
(-16.40)\end{array}$ & $\begin{array}{l}-0.23^{\star \star \star} \\
(-18.64)\end{array}$ & $\begin{array}{l}-0.09^{\star \star \star} \\
(-3.26)\end{array}$ & & \\
\hline ASSETS & & & & $\begin{array}{l}-0.25^{\star \star \star} \\
(-8.02)\end{array}$ & $\begin{array}{l}-0.48^{* * *} \\
(-6.17)\end{array}$ \\
\hline ASSETS $^{2}$ & & & & $\begin{array}{l}0.03^{\star \star \star} \\
(4.24)\end{array}$ & $\begin{array}{l}0.04^{* *} \\
(2.04)\end{array}$ \\
\hline AGE & & & & $\begin{array}{l}-0.14^{\star \star \star} \\
(-7.61)\end{array}$ & $\begin{array}{l}-0.41^{\star \star *} \\
(-9.74)\end{array}$ \\
\hline $\mathrm{AGE}^{2}$ & & & & $\begin{array}{l}0.02^{\star \star \star} \\
(6.58)\end{array}$ & $\begin{array}{l}0.05^{\star \star \star} \\
(8.44)\end{array}$ \\
\hline LEVERAGE & & & $\begin{array}{l}-0.07^{\text {***}} \\
(-2.75)\end{array}$ & $\begin{array}{l}-0.05^{\star} \\
(-1.88)\end{array}$ & $\begin{array}{c}0.05 \\
(0.88)\end{array}$ \\
\hline TANGIBILITY & & & $\begin{array}{c}0.03 \\
(0.68)\end{array}$ & $\begin{array}{c}0.04 \\
(0.78)\end{array}$ & $\begin{array}{c}0.14 \\
(1.28)\end{array}$ \\
\hline $\mathrm{ROA}$ & & & $\begin{array}{l}0.42^{* * *} \\
(16.38)\end{array}$ & $\begin{array}{l}0.35^{\star \star \star} \\
(13.07)\end{array}$ & $\begin{array}{l}0.19^{* \star *} \\
(2.65)\end{array}$ \\
\hline $\mathrm{CASH}$ & & & $\begin{array}{l}0.67^{\star \star *} \\
(18.58)\end{array}$ & $\begin{array}{l}0.71^{\star \star \star} \\
(19.39)\end{array}$ & $\begin{array}{l}1.62^{\star \star \star} \\
(16.08)\end{array}$ \\
\hline SALES_GROWTH & & & $\begin{array}{c}0.34^{\star \star *} \\
(16.66)\end{array}$ & $\begin{array}{c}0.26^{\star \star \star} \\
(13.36)\end{array}$ & $\begin{array}{l}0.47^{\star \star *} \\
(9.00)\end{array}$ \\
\hline RD_CAPITAL & & & $\begin{array}{l}0.01^{* * *} \\
(4.15)\end{array}$ & $\begin{array}{l}0.01^{\star \star \star} \\
(4.45)\end{array}$ & $\begin{array}{l}0.03^{\star \star \star} \\
(4.65)\end{array}$ \\
\hline CAPEX & & & $\begin{array}{l}0.12^{\star \star \star} \\
(7.77)\end{array}$ & $\begin{array}{l}0.10^{\star \star \star} \\
(6.08)\end{array}$ & $\begin{array}{l}0.18^{\star \star \star} \\
(3.87)\end{array}$ \\
\hline DIVIDEND & & & $\begin{array}{c}0.13^{* * *} \\
(10.51)\end{array}$ & $\begin{array}{l}0.11^{\star \star \star} \\
(9.30)\end{array}$ & $\begin{array}{l}0.12^{* \star *} \\
(4.81)\end{array}$ \\
\hline $\begin{array}{l}\text { Firm fixed effects } \\
\text { Year fixed effects }\end{array}$ & $\begin{array}{l}\text { No } \\
\text { No }\end{array}$ & $\begin{array}{l}\text { Yes } \\
\text { No }\end{array}$ & $\begin{array}{l}\text { Yes } \\
\text { Yes }\end{array}$ & $\begin{array}{l}\text { Yes } \\
\text { Yes }\end{array}$ & $\begin{array}{l}\text { Yes } \\
\text { Yes }\end{array}$ \\
\hline $\begin{array}{l}\text { Obs. } \\
R^{2}\end{array}$ & $\begin{array}{c}88,527 \\
0.02\end{array}$ & $\begin{array}{c}88,527 \\
0.04\end{array}$ & $\begin{array}{c}74,087 \\
0.18\end{array}$ & $\begin{array}{c}74,087 \\
0.16\end{array}$ & $\begin{array}{c}74,087 \\
0.09\end{array}$ \\
\hline
\end{tabular}

A possible alternative explanation for the decreasing $\mathrm{Q}$ in firm age and size is decreasing return to scale. That is, as a firm grows, asset size increases but the marginal ROA decreases, causing $\mathrm{Q}$ to decrease. Contradicting this explanation, however, in our sample, larger or older firms on average have higher ROA (see Figure 2). There is probably a survival effect because more profitable firms are more likely to survive over time, resulting in the increasing ROA pattern. However, even when we use a balanced panel including only firms that survive the entire sample period, the increasing ROA pattern in Figure 2 remains. This suggests that decreasing return to scale does not explain the dynamics of firm valuation. 
FIGURE 2

ROA over Asset Size and Firm Age

Figure 2 plots the average return on assets ( $R O A$ ) over asset size (Graph $A$ ) and firm age (Graph $B)$. ROA is the ratio of income before extraordinary items over book assets. Asset size is measured by the firm's book assets. When forming the 20 book-assets quantiles, we first use the CPI to adjust book assets into constant dollar value. Firm age is the number of years a firm has appeared in Compustat. The sample consists of Center for Research in Security Prices (CRSP)/Compustat firms from 1991 to 2012.
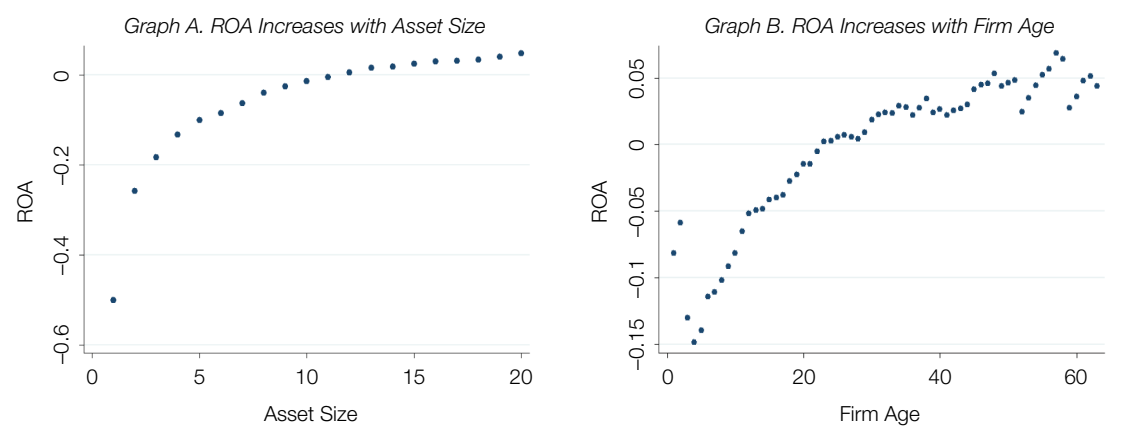

We next test Hypothesis 1's prediction regarding CFV in Table 3. Table 3 contains a set of tests parallel to Table 2 , but the dependent variable is $\ln (\mathrm{CFV})$. Results in columns 1-3 confirm that CFV decreases as firms grow larger and older. Results in columns 4 and 5 suggest that the decrease of CFV has a decreasing speed as firms grow larger and older. Tables 2 and 3 together provide strong results consistent with Hypothesis 1.

\section{The CFV-Q Association}

Our model predicts a positive association between CFV and Q because both CFV and Q decrease as a firm grows. In this section, we test this prediction and various conditions that are expected to affect the dynamics of the CFV-Q association.

\section{Firm Growth and the CFV-Q Association}

Table 4 shows empirical results for Hypothesis 2. Column 1 reports the OLS specification of regressing firm $\ln (\mathrm{Q})$ on $\ln (\mathrm{CFV})$, with industry and year fixed effects but without firm fixed effects. We also exclude size and age from the regression because in our theoretical model, both CFV and Q, as well as their association, are a function of firm growth over time (proxied by assets size and age). The coefficient on $\ln (\mathrm{CFV})$ is positive and highly significant. In column 2 , we implement firm fixed effects specification. The coefficient on $\ln (\mathrm{CFV})$ becomes larger and more significant. The coefficient estimate of 0.12 implies that a $1 \%$ increase in $\mathrm{CFV}$ is associated with a $0.12 \%$ increase in firm Q. As mentioned earlier, our model primarily shows the time-series properties of firm growth, so we implement firm fixed effect regressions as our main empirical methodology. Our model's predictions can also be generalized to the cross section if firm heterogeneity is adequately controlled for. In an untabulated robustness check, we implement the purely cross-sectional Fama-MacBeth (1973) specification. The coefficient on $\ln (\mathrm{CFV})$ becomes smaller but is still positive and highly significant. 
TABLE 3

Change in CFV as Firms Grow

Table 3 reports results of firm fixed effects and pooled ordinary least squares (OLS) regressions where the dependent variable is In(CFV). We study how firm growth, proxied by firm size (ASSETS) and firm age (AGE), affects cash-flow volatility (CFV). Model 1 is a pooled OLS regression without controls. Model 2 includes firm fixed effects. Models 3 and 4 add all additional controls. To capture the nonlinear effect of firm growth on CFV, models 4 and 5 add quadratic terms of assets and age. The dependent variable in model 5 is unlogged CFV. For purely aesthetic reasons, in models 4 and 5 , the coefficient estimate for assets is multiplied by 10,000 , for age by 10 . An intercept is included but not reported. $R^{2}$ for firm fixed effects is the within $R^{2}$; for OLS is the adjusted $R^{2}$. Standard errors are clustered at the firm level and corrected for heteroskedasticity. Variables of interest are in bold, and $t$-values are reported in parentheses. ${ }^{*},{ }^{* *}$, and ${ }^{* * *}$ indicate significance at the $10 \%, 5 \%$, and $1 \%$ levels, respectively.

\begin{tabular}{|c|c|c|c|c|c|}
\hline $\begin{array}{c}\text { Dependent } \\
\text { Variable }\end{array}$ & $\begin{array}{c}\text { OLS } \\
\operatorname{In}(\mathrm{CFV}) \\
1\end{array}$ & $\begin{array}{c}\text { Firm } \\
\text { Fixed Effects } \\
\text { In(CFV) } \\
2\end{array}$ & $\begin{array}{c}\text { Firm } \\
\text { Fixed Effects } \\
\text { In(CFV) } \\
3\end{array}$ & $\begin{array}{c}\text { Firm } \\
\text { Fixed Effects } \\
\text { In(CFV) } \\
4\end{array}$ & $\begin{array}{c}\text { Firm } \\
\text { Fixed Effects } \\
\text { CFV } \\
5\end{array}$ \\
\hline In(ASSETS) & $\begin{array}{l}-0.19^{\star \star \star} \\
(-54.09)\end{array}$ & $\begin{array}{l}-0.17^{\star \star \star} \\
(-25.54)\end{array}$ & $\begin{array}{l}-0.19^{\star \star \star} \\
(-24.47)\end{array}$ & & \\
\hline $\ln (A G E)$ & $\begin{array}{l}-0.09^{\star \star \star} \\
(-10.05)\end{array}$ & $\begin{array}{l}-0.12^{\star \star \star} \\
(-10.08)\end{array}$ & $\begin{array}{l}-0.08^{\star \star \star} \\
(-2.73)\end{array}$ & & \\
\hline ASSETS & & & & $\begin{array}{l}-0.35^{\star \star \star} \\
(-7.74)\end{array}$ & $\begin{array}{l}-0.01^{* \star *} \\
(-4.00)\end{array}$ \\
\hline ASSETS $^{2}$ & & & & $\begin{array}{l}0.05^{\star \star \star} \\
(5.50)\end{array}$ & $\begin{array}{l}0.001^{* \star *} \\
(2.60)\end{array}$ \\
\hline AGE & & & & $\begin{array}{c}-0.23^{\star \star \star} \\
(-11.83)\end{array}$ & $\begin{array}{l}-0.01^{\star \star \star} \\
(-8.51)\end{array}$ \\
\hline $\mathrm{AGE}^{2}$ & & & & $\begin{array}{l}0.02^{* \star \star} \\
(6.44)\end{array}$ & 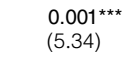 \\
\hline LEVERAGE & & & $\begin{array}{l}0.08^{\star * \star} \\
(4.42)\end{array}$ & $\begin{array}{l}0.11^{\star \star \star} \\
(5.85)\end{array}$ & $\begin{array}{l}0.01^{\star \star *} \\
(4.03)\end{array}$ \\
\hline TANGIBILITY & & & $\begin{array}{l}-0.20^{* * *} \\
(-4.33)\end{array}$ & $\begin{array}{l}-0.18^{\star \star \star} \\
(-3.71)\end{array}$ & $\begin{array}{l}-0.01^{* \star *} \\
(-3.58)\end{array}$ \\
\hline $\mathrm{ROA}$ & & & $\begin{array}{l}0.09^{\star * *} \\
(5.26)\end{array}$ & $\begin{array}{l}-0.02 \\
(-0.92)\end{array}$ & $\begin{array}{l}-0.00^{\star *} \\
(-2.22)\end{array}$ \\
\hline $\mathrm{CASH}$ & & & $\begin{array}{l}0.27^{* * *} \\
(8.93)\end{array}$ & $\begin{array}{c}0.33^{\star \star \star} \\
(10.24)\end{array}$ & $\begin{array}{l}0.02^{\star \star \star} \\
(7.73)\end{array}$ \\
\hline SALES_GROWTH & & & $\begin{array}{l}0.22^{* * *} \\
(11.78)\end{array}$ & $\begin{array}{l}0.11^{\star \star \star} \\
(5.80)\end{array}$ & $\begin{array}{l}0.01^{* \star *} \\
(4.06)\end{array}$ \\
\hline RD_CAPITAL & & & $\begin{array}{c}0.00 \\
(1.47)\end{array}$ & $\begin{array}{r}0.00^{*} \\
(1.86)\end{array}$ & $\begin{array}{l}0.00^{\star *} \\
(2.49)\end{array}$ \\
\hline CAPEX & & & $\begin{array}{l}0.06^{* * *} \\
(5.62)\end{array}$ & $\begin{array}{l}0.03^{\star \star \star} \\
(2.60)\end{array}$ & $\begin{array}{l}0.00^{\star *} \\
(2.43)\end{array}$ \\
\hline DIVIDEND & & & $\begin{array}{c}0.00 \\
(0.32)\end{array}$ & $\begin{array}{l}-0.02 \\
(-1.30)\end{array}$ & $\begin{array}{l}-0.00 \\
(-0.70)\end{array}$ \\
\hline $\begin{array}{l}\text { Firm fixed effects } \\
\text { Year fixed effects }\end{array}$ & $\begin{array}{l}\text { No } \\
\text { No }\end{array}$ & $\begin{array}{l}\text { Yes } \\
\text { No }\end{array}$ & $\begin{array}{l}\text { Yes } \\
\text { Yes }\end{array}$ & $\begin{array}{l}\text { Yes } \\
\text { Yes }\end{array}$ & $\begin{array}{l}\text { Yes } \\
\text { Yes }\end{array}$ \\
\hline $\begin{array}{l}\text { Obs. } \\
R^{2}\end{array}$ & $\begin{array}{c}88,527 \\
0.28\end{array}$ & $\begin{array}{c}88,527 \\
0.09\end{array}$ & $\begin{array}{c}74,087 \\
0.12\end{array}$ & $\begin{array}{c}74,087 \\
0.08\end{array}$ & $\begin{array}{c}74,087 \\
0.12\end{array}$ \\
\hline
\end{tabular}

In columns 3 and 4, we add size and age as additional controls. We expect the coefficient on $\ln (\mathrm{CFV})$ to become smaller because size and age are significant determinants of $\mathrm{Q}$. The coefficient estimate on $\ln (\mathrm{CFV})$ does decrease in the firm fixed effects specification, but increases slightly in the OLS specification, likely because OLS cannot adequately control for firm heterogeneity.

Our Hypothesis 2 also predicts that the positive CFV-Q association will be more pronounced for smaller firms and younger firms because these firms likely have larger investment opportunities. We sort firms by book assets size or firm age for each year, and create a SMALL dummy and a YOUNG dummy that equal 1 for firms with below-median size or age. As outlined in model (14), we interact the SMALL and YOUNG dummies with $\ln (\mathrm{CFV})$. Both OLS and firm fixed effects 
TABLE 4

Association between CFV and Firm Valuation (Q)

Table 4 reports results of firm fixed effects and pooled ordinary least squares (OLS) regressions where the dependent variable is $\ln (\mathrm{Q})$. We study how firm valuation is associated with cash-flow volatility (CFV): the CFV-Q association. Models 1-4 examine the CFV-Q association directly, which is captured by the coefficient of $\ln (\mathrm{CFV})$. Models 5 and 6 and models 7 and 8 examine, respectively, how firm size and firm age affect the CFV-Q association by including an interaction term (SMALL $\times \operatorname{In}(\mathrm{CFV})$ or YOUNG $\times \operatorname{In}(\mathrm{CFV})$ ) in the regression. SMALL and YOUNG are dummies for small and young firms. The coefficients of the interaction terms capture differences of the CFV-Q association between small (young) and large (old) firms. An intercept is included but not reported. $R^{2}$ for firm fixed effects is the within $R^{2}$; for OLS is the adjusted $R^{2}$. Standard errors are clustered at the firm level and corrected for heteroskedasticity. Variables of interest are in bold, and $t$-values are reported in parentheses. ${ }^{* \star}$ and ${ }^{* *}$ indicate significance at the $5 \%$ and $1 \%$ levels, respectively.

\begin{tabular}{|c|c|c|c|c|c|c|c|c|}
\hline & OLS & $\begin{array}{c}\text { Firm } \\
\text { Fixed Effects }\end{array}$ & OLS & $\begin{array}{c}\text { Firm } \\
\text { Fixed Effects }\end{array}$ & OLS & $\begin{array}{c}\text { Firm } \\
\text { Fixed Effects }\end{array}$ & OLS & $\begin{array}{c}\text { Firm } \\
\text { Fixed Effects }\end{array}$ \\
\hline & 1 & 2 & 3 & 4 & 5 & 6 & 7 & 8 \\
\hline $\ln (\mathrm{CFV})$ & $\begin{array}{l}0.05^{\star \star \star} \\
(6.19)\end{array}$ & $\begin{array}{c}0.12^{\star \star \star} \\
(14.02)\end{array}$ & $\begin{array}{l}0.06^{\star \star \star} \\
(7.43)\end{array}$ & $\begin{array}{l}0.08^{\star \star \star} \\
(9.90)\end{array}$ & $\begin{array}{c}0.00 \\
(0.19)\end{array}$ & $\begin{array}{l}0.06^{* * *} \\
(6.47)\end{array}$ & $\begin{array}{l}0.04^{* * *} \\
(4.23)\end{array}$ & $\begin{array}{l}0.07^{* \star *} \\
(7.44)\end{array}$ \\
\hline SMALL & & & & & $\begin{array}{l}0.26^{* * *} \\
(5.28)\end{array}$ & $\begin{array}{l}0.15^{\star \star \star} \\
(3.12)\end{array}$ & & \\
\hline SMALL $\times \ln (C F V)$ & & & & & $\begin{array}{l}0.14^{\star \star \star} \\
(9.56)\end{array}$ & $\begin{array}{l}0.06^{\star \star \star} \\
(4.41)\end{array}$ & & \\
\hline YOUNG & & & & & & & $\begin{array}{l}0.09^{* *} \\
(2.04)\end{array}$ & $\begin{array}{l}0.15^{\star * \star} \\
(3.48)\end{array}$ \\
\hline YOUNG $\times \ln (C F V)$ & & & & & & & $\begin{array}{l}0.04^{\star \star \star} \\
(3.33)\end{array}$ & $\begin{array}{l}0.04^{* * \star} \\
(3.05)\end{array}$ \\
\hline In(ASSETS) & & & $\begin{array}{l}0.02^{\star * *} \\
(4.52)\end{array}$ & $\begin{array}{l}-0.12^{\star \star *} \\
(-15.56)\end{array}$ & $\begin{array}{l}-0.02^{* * *} \\
(-3.93)\end{array}$ & $\begin{array}{l}-0.13^{\star \star \star} \\
(-15.85)\end{array}$ & $\begin{array}{l}0.02^{* \star *} \\
(4.64)\end{array}$ & $\begin{array}{l}-0.12^{* \star *} \\
(-15.62)\end{array}$ \\
\hline $\ln (A G E)$ & & & $\begin{array}{l}-0.04^{\star * *} \\
(-3.81)\end{array}$ & $\begin{array}{l}-0.09^{\star \star *} \\
(-3.02)\end{array}$ & $\begin{array}{l}-0.04^{\star * *} \\
(-3.53)\end{array}$ & $\begin{array}{l}-0.08^{\text {*** }} \\
(-2.86)\end{array}$ & $\begin{array}{l}-0.07^{\star \star \star} \\
(-4.75)\end{array}$ & $\begin{array}{l}-0.04 \\
(-1.40)\end{array}$ \\
\hline LEVERAGE & $\begin{array}{l}-0.09^{\star \star \star *} \\
(-3.41)\end{array}$ & $\begin{array}{l}-0.06^{\star *} \\
(-2.31)\end{array}$ & $\begin{array}{l}-0.10^{\star \star \star} \\
(-3.91)\end{array}$ & $\begin{array}{l}-0.07^{\star \star *} \\
(-3.05)\end{array}$ & $\begin{array}{l}-0.12^{\star \star *} \\
(-4.44)\end{array}$ & $\begin{array}{l}-0.08^{* \star *} \\
(-3.19)\end{array}$ & $\begin{array}{l}-0.10^{\star * *} \\
(-3.84)\end{array}$ & 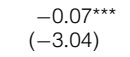 \\
\hline TANGIBILITY & $\begin{array}{c}0.04 \\
(1.18)\end{array}$ & $\begin{array}{c}0.08 \\
(1.58)\end{array}$ & $\begin{array}{c}0.04 \\
(1.02)\end{array}$ & $\begin{array}{c}0.05 \\
(1.03)\end{array}$ & $\begin{array}{c}0.05 \\
(1.44)\end{array}$ & $\begin{array}{c}0.05 \\
(1.13)\end{array}$ & $\begin{array}{c}0.03 \\
(0.94)\end{array}$ & $\begin{array}{c}0.05 \\
(1.07)\end{array}$ \\
\hline $\mathrm{ROA}$ & $\begin{array}{l}0.16^{\star * *} \\
(5.22)\end{array}$ & $\begin{array}{l}0.35^{\star \star *} \\
(13.32)\end{array}$ & $\begin{array}{l}0.14^{\star \star \star} \\
(4.32)\end{array}$ & $\begin{array}{l}0.42^{\star \star *} \\
(16.16)\end{array}$ & $\begin{array}{l}0.17^{\star \star \star} \\
(5.66)\end{array}$ & $\begin{array}{l}0.42^{\star * *} \\
(16.45)\end{array}$ & $\begin{array}{l}0.14^{* \star *} \\
(4.39)\end{array}$ & $\begin{array}{l}0.42^{\star \star *} \\
(16.13)\end{array}$ \\
\hline $\mathrm{CASH}$ & $\begin{array}{l}1.03^{\star \star \star *} \\
(28.28)\end{array}$ & $\begin{array}{c}0.70^{* \star *} \\
(19.31)\end{array}$ & $\begin{array}{l}1.02^{* * *} \\
(28.09)\end{array}$ & $\begin{array}{c}0.65^{\star \star *} \\
(18.03)\end{array}$ & $\begin{array}{l}1.02^{* * *} \\
(28.58)\end{array}$ & $\begin{array}{c}0.65^{\star \star *} \\
(17.96)\end{array}$ & $\begin{array}{l}1.02^{* \star *} \\
(28.00)\end{array}$ & $\begin{array}{l}0.65^{* * *} \\
(18.07)\end{array}$ \\
\hline SALES_GROWTH & $\begin{array}{l}0.51^{* \star *} \\
(26.91)\end{array}$ & $\begin{array}{c}0.26^{\star \star *} \\
(13.43)\end{array}$ & 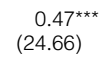 & $\begin{array}{c}0.32^{\star \star *} \\
(15.83)\end{array}$ & 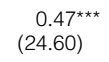 & $\begin{array}{c}0.32^{* * *} \\
(15.83)\end{array}$ & $\begin{array}{l}0.47^{\star \star *} \\
(24.56)\end{array}$ & $\begin{array}{c}0.32^{\star \star \star} \\
(15.86)\end{array}$ \\
\hline RD_CAPITAL & 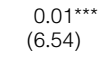 & $\begin{array}{l}0.01^{* * *} \\
(4.37)\end{array}$ & $\begin{array}{l}0.01^{* \star *} \\
(6.42)\end{array}$ & $\begin{array}{l}0.01^{* * *} \\
(4.08)\end{array}$ & $\begin{array}{l}0.01^{* * *} \\
(6.05)\end{array}$ & $\begin{array}{l}0.01^{* * *} \\
(3.98)\end{array}$ & $\begin{array}{l}0.01^{* \star *} \\
(6.34)\end{array}$ & $\begin{array}{l}0.01^{* * *} \\
(4.01)\end{array}$ \\
\hline CAPEX & $\begin{array}{l}0.13^{* * *} \\
(8.81)\end{array}$ & $\begin{array}{l}0.09^{\star \star *} \\
(6.01)\end{array}$ & $\begin{array}{l}0.13^{\star * *} \\
(8.38)\end{array}$ & $\begin{array}{l}0.11^{\star \star \star} \\
(7.51)\end{array}$ & $\begin{array}{l}0.13^{\star \star \star} \\
(8.42)\end{array}$ & $\begin{array}{l}0.11^{\star \star *} \\
(7.52)\end{array}$ & $\begin{array}{l}0.13^{* * *} \\
(8.51)\end{array}$ & $\begin{array}{l}0.11^{\star \star \star} \\
(7.52)\end{array}$ \\
\hline DIVIDEND & $\begin{array}{c}0.19^{\star \star \star \star} \\
(15.95)\end{array}$ & $\begin{array}{l}0.10^{\star \star *} \\
(8.26)\end{array}$ & $\begin{array}{c}0.19^{* * *} \\
(14.08)\end{array}$ & $\begin{array}{c}0.13^{\star * *} \\
(10.54)\end{array}$ & $\begin{array}{c}0.18^{* * *} \\
(13.64)\end{array}$ & $\begin{array}{c}0.13^{* * *} \\
(10.44)\end{array}$ & 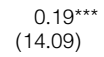 & $\begin{array}{c}0.13^{* * *} \\
(10.51)\end{array}$ \\
\hline $\begin{array}{l}\text { Firm fixed effects } \\
\text { Industry fixed effects } \\
\text { Year fixed effects }\end{array}$ & $\begin{array}{l}\text { No } \\
\text { Yes } \\
\text { Yes }\end{array}$ & $\begin{array}{l}\text { Yes } \\
\text { No } \\
\text { Yes }\end{array}$ & $\begin{array}{l}\text { No } \\
\text { Yes } \\
\text { Yes }\end{array}$ & $\begin{array}{l}\text { Yes } \\
\text { No } \\
\text { Yes }\end{array}$ & $\begin{array}{l}\text { No } \\
\text { Yes } \\
\text { Yes }\end{array}$ & $\begin{array}{l}\text { Yes } \\
\text { No } \\
\text { Yes }\end{array}$ & $\begin{array}{l}\text { No } \\
\text { Yes } \\
\text { Yes }\end{array}$ & $\begin{array}{l}\text { Yes } \\
\text { No } \\
\text { Yes }\end{array}$ \\
\hline $\begin{array}{l}\text { Obs. } \\
R^{2}\end{array}$ & $\begin{array}{c}74,087 \\
0.27\end{array}$ & $\begin{array}{c}74,087 \\
0.17 \\
\end{array}$ & $\begin{array}{c}74,087 \\
0.27\end{array}$ & $\begin{array}{c}74,087 \\
0.18 \\
\end{array}$ & $\begin{array}{c}74,087 \\
0.28 \\
\end{array}$ & $\begin{array}{c}74,087 \\
0.18 \\
\end{array}$ & $\begin{array}{c}74,087 \\
0.27\end{array}$ & $\begin{array}{c}74,087 \\
0.18 \\
\end{array}$ \\
\hline
\end{tabular}

results show that the positive CFV-Q association is significantly larger for smaller firms (columns 5 and 6) and younger firms (columns 7 and 8).

Overall, the results in Table 4 are consistent with our Hypothesis 2 that Q is positively associated with $\mathrm{CFV}$, and this association is more pronounced for small and young firms.

\section{How Do Growth Opportunities Affect the CFV-Q Association?}

Hypothesis 3 predicts that the positive $\mathrm{CFV}-\mathrm{Q}$ association is more pronounced for firms with larger growth opportunities. We identify 3 proxies for growth opportunities: R\&D capital, annualized sales growth rate in the past 5 
years, and whether a firm has filed a patent in that year. We create 3 dummy variables that equal 1 if in a given year a firm has above-median R\&D capital, has above-median sales growth, or files a positive number of patents. We interact these dummies with $\ln (\mathrm{CFV})$ and expect positive coefficients on the interaction terms. The results are in Table 5. Both OLS and firm fixed effects results are consistent with the prediction that the CFV-Q association is more positive for firms with larger growth opportunities. The only weak result is the OLS specification

\section{TABLE 5}

\section{How Do Growth Opportunities Affect the CFV-Q Association?}

Table 5 reports results of firm fixed effects and pooled ordinary least squares (OLS) regressions where the dependent variable is $\operatorname{In}(\mathrm{Q})$. We study how firm's growth opportunities affect the CFV-Q association by including an interaction term between cash-flow volatility (In(CFV)) and the proxy dummies for growth opportunities, RDC, G_GROWTH, or D_PATENT. $\mathrm{RDC}=1$ for firms with above-median research and development (R\&D) capital stock, S_GROWTH=1 for firms having above-median sales growth in the past 5 years, and DPatent $=1$ for firms having positive number of patents. The coefficients of the interaction terms capture the difference in the CFV-Q association between firms with low and high growth opportunities. An intercept is included but not reported. $R^{2}$ for firm fixed effects is the within $R^{2}$; for OLS is the adjusted $R^{2}$. Standard errors are clustered at the firm level and corrected for heteroskedasticity. Variables of interest are in bold, and $t$-values are reported in parentheses. ${ }^{* *}$ and ${ }^{* * *}$ indicate significance at the $5 \%$ and $1 \%$ levels, respectively.

\begin{tabular}{|c|c|c|c|c|c|c|}
\hline & $\begin{array}{c}\text { OLS } \\
1\end{array}$ & $\begin{array}{c}\begin{array}{c}\text { Firm } \\
\text { Fixed Effects } \\
2 \\
\end{array} \\
\end{array}$ & $\begin{array}{c}\text { OLS } \\
3\end{array}$ & $\begin{array}{c}\begin{array}{c}\text { Firm } \\
\text { Fixed Effects } \\
4 \\
\end{array} \\
\end{array}$ & $\begin{array}{c}\text { OLS } \\
5 \\
\end{array}$ & $\begin{array}{c}\begin{array}{c}\text { Firm } \\
\text { Fixed Effects } \\
6 \\
\end{array} \\
\end{array}$ \\
\hline $\ln (\mathrm{CFV})$ & $\begin{array}{c}0.00 \\
(0.02)\end{array}$ & $\begin{array}{l}0.05^{\star \star \star} \\
(4.43)\end{array}$ & $\begin{array}{l}0.05^{* * *} \\
(4.87)\end{array}$ & $\begin{array}{l}0.08^{\star \star *} \\
(8.46)\end{array}$ & $\begin{array}{l}0.06^{\star \star \star *} \\
(7.00)\end{array}$ & $\begin{array}{l}0.08^{* * *} \\
(8.76)\end{array}$ \\
\hline RDC & $\begin{array}{c}0.67^{\star \star *} \\
(13.21)\end{array}$ & $\begin{array}{l}0.26^{\star \star \star} \\
(4.45)\end{array}$ & & & & \\
\hline $\mathrm{RDC} \times \ln (\mathrm{CFV})$ & $\begin{array}{l}0.14^{\star \star \star *} \\
(9.77)\end{array}$ & $\begin{array}{l}0.07^{\star \star \star} \\
(4.67)\end{array}$ & & & & \\
\hline S_GROWTH & & & $\begin{array}{l}0.32^{\star \star \star *} \\
(8.45)\end{array}$ & $\begin{array}{l}0.24^{\star \star \star} \\
(7.80)\end{array}$ & & \\
\hline S_GROWTH $\times \ln (\mathrm{CFV})$ & & & $\begin{array}{l}0.03^{\star \star} \\
(2.41)\end{array}$ & $\begin{array}{l}0.02^{* *} \\
(2.34)\end{array}$ & & \\
\hline D_PATENT & & & & & $\begin{array}{l}0.26^{\star \star \star *} \\
(4.49)\end{array}$ & $\begin{array}{l}0.18^{\star * \star} \\
(4.36)\end{array}$ \\
\hline D_PATENT $\times \ln (\mathrm{CFV})$ & & & & & $\begin{array}{c}0.02 \\
(1.31)\end{array}$ & $\begin{array}{l}0.04^{\star \star \star} \\
(3.66)\end{array}$ \\
\hline In(ASSETS) & $\begin{array}{l}0.02^{\star * *} \\
(4.17)\end{array}$ & $\begin{array}{c}-0.12^{\star \star \star} \\
(-15.54)\end{array}$ & $\begin{array}{l}0.01^{* \star *} \\
(3.30)\end{array}$ & $\begin{array}{c}-0.13^{\star \star \star} \\
(-16.19)\end{array}$ & $\begin{array}{l}0.01^{\star \star \star *} \\
(2.62)\end{array}$ & $\begin{array}{c}-0.12^{\star \star \star} \\
(-15.75)\end{array}$ \\
\hline $\ln (A G E)$ & $\begin{array}{l}-0.04^{\star * *} \\
(-3.93)\end{array}$ & $\begin{array}{l}-0.09^{\star \star \star} \\
(-3.04)\end{array}$ & $\begin{array}{l}-0.01 \\
(-1.46)\end{array}$ & $\begin{array}{l}-0.12^{\star \star \star} \\
(-4.27)\end{array}$ & $\begin{array}{l}-0.05^{\star \star \star} \\
(-4.50)\end{array}$ & $\begin{array}{l}-0.09^{* * *} \\
(-3.05)\end{array}$ \\
\hline LEVERAGE & $\begin{array}{l}-0.10^{\star \star \star} \\
(-3.75)\end{array}$ & $\begin{array}{l}-0.08^{\star \star \star} \\
(-3.18)\end{array}$ & $\begin{array}{l}-0.08^{\star \star *} \\
(-3.22)\end{array}$ & $\begin{array}{l}-0.07^{\star \star \star} \\
(-3.13)\end{array}$ & $\begin{array}{l}-0.10^{\star \star \star} \\
(-3.73)\end{array}$ & $\begin{array}{l}-0.07^{\star * \star} \\
(-3.02)\end{array}$ \\
\hline TANGIBILITY & $\begin{array}{c}0.04 \\
(1.22)\end{array}$ & $\begin{array}{c}0.04 \\
(0.83)\end{array}$ & $\begin{array}{c}0.04 \\
(1.11)\end{array}$ & $\begin{array}{c}0.07 \\
(1.42)\end{array}$ & $\begin{array}{c}0.03 \\
(0.79)\end{array}$ & $\begin{array}{c}0.05 \\
(0.97)\end{array}$ \\
\hline $\mathrm{ROA}$ & $\begin{array}{l}0.16^{\star * *} \\
(5.34)\end{array}$ & $\begin{array}{c}0.41^{\star \star \star} \\
(15.69)\end{array}$ & $\begin{array}{l}0.11^{* * *} \\
(3.51)\end{array}$ & $\begin{array}{l}0.41^{\star * *} \\
(16.17)\end{array}$ & $\begin{array}{l}0.14^{\star \star \star *} \\
(4.55)\end{array}$ & $\begin{array}{l}0.42^{\star \star \star} \\
(16.19)\end{array}$ \\
\hline $\mathrm{CASH}$ & $\begin{array}{c}0.98^{\star \star \star} \\
(27.77)\end{array}$ & $\begin{array}{c}0.66^{\star \star \star} \\
(18.13)\end{array}$ & $\begin{array}{l}1.03^{\star \star *} \\
(28.98)\end{array}$ & $\begin{array}{c}0.66^{\star \star \star} \\
(18.16)\end{array}$ & $\begin{array}{c}0.97^{\star \star \star} \\
(27.22)\end{array}$ & $\begin{array}{c}0.65^{\star \star \star} \\
(17.96)\end{array}$ \\
\hline SALES_GROWTH & $\begin{array}{l}0.46^{\star \star *} \\
(24.33)\end{array}$ & $\begin{array}{c}0.31^{\star \star \star} \\
(15.63)\end{array}$ & & & $\begin{array}{c}0.46^{\star \star \star} \\
(24.60)\end{array}$ & $\begin{array}{l}0.32^{\star * \star} \\
(15.79)\end{array}$ \\
\hline RD_CAPITAL & & & $\begin{array}{l}0.01^{\star \star \star} \\
(6.77)\end{array}$ & $\begin{array}{l}0.01^{* \star *} \\
(3.83)\end{array}$ & 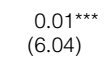 & $\begin{array}{l}0.01^{* \star \star} \\
(4.02)\end{array}$ \\
\hline CAPEX & $\begin{array}{c}0.17^{\star \star \star} \\
(11.79)\end{array}$ & $\begin{array}{l}0.13^{\star \star \star} \\
(8.68)\end{array}$ & $\begin{array}{l}0.13^{\star \star \star} \\
(8.42)\end{array}$ & $\begin{array}{l}0.10^{\star \star \star} \\
(6.53)\end{array}$ & 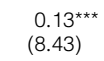 & $\begin{array}{l}0.11^{* \star \star} \\
(7.47)\end{array}$ \\
\hline DIVIDEND & $\begin{array}{c}0.19^{* \star *} \\
(14.64)\end{array}$ & $\begin{array}{c}0.13^{\star \star \star} \\
(10.55)\end{array}$ & $\begin{array}{c}0.19^{\star \star \star} \\
(15.01)\end{array}$ & $\begin{array}{c}0.13^{\star \star \star} \\
(10.60)\end{array}$ & $\begin{array}{c}0.19^{\star \star \star} \\
(14.59)\end{array}$ & 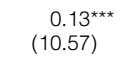 \\
\hline $\begin{array}{l}\text { Firm fixed effects } \\
\text { Industry fixed effects } \\
\text { Year fixed effects }\end{array}$ & $\begin{array}{l}\text { No } \\
\text { Yes } \\
\text { Yes }\end{array}$ & $\begin{array}{l}\text { Yes } \\
\text { No } \\
\text { Yes }\end{array}$ & $\begin{array}{l}\text { No } \\
\text { Yes } \\
\text { Yes }\end{array}$ & $\begin{array}{l}\text { Yes } \\
\text { No } \\
\text { Yes }\end{array}$ & $\begin{array}{l}\text { No } \\
\text { Yes } \\
\text { Yes }\end{array}$ & $\begin{array}{l}\text { Yes } \\
\text { No } \\
\text { Yes }\end{array}$ \\
\hline $\begin{array}{l}\text { Obs. } \\
R^{2}\end{array}$ & $\begin{array}{c}74,087 \\
0.28\end{array}$ & $\begin{array}{c}74,087 \\
0.18\end{array}$ & $\begin{array}{c}74,087 \\
0.28\end{array}$ & $\begin{array}{c}74,087 \\
0.19\end{array}$ & $\begin{array}{c}74,087 \\
0.28\end{array}$ & $\begin{array}{c}74,087 \\
0.18\end{array}$ \\
\hline
\end{tabular}


in column 5, in which the interaction between the patent dummy and CFV is not statistically significant at the conventional level $(t=1.31)$.

\section{Correlation of Cross-Segment Cash Flows and the CFV-Q Association}

Our model shows that the internal correlation of cash flows across a firm's segments affects its CFV and the CFV-Q association. We do not have a direct measure of internal cash-flow correlation across segments. As discussed earlier, we use the number of business segments from Compustat as a proxy for cashflow correlation. Firms with fewer business segments likely have higher cashflow correlation across market segments, and single-business-segment firms likely have even higher cash-flow correlation across market segments. Confirming this expectation, in an untabulated test, we find that firm's CFV is negatively correlated with its number of business segments.

We then test Hypothesis 4 and report the results in Table 6. Because the number of business segments for most firms does not vary much over time, we expect the effect to be more visible across firms than within a firm. In columns 13 , we include the interaction term between $\ln (\mathrm{CFV})$ and the number of business segments reported in Compustat. As expected, the positive CFV-Q association decreases as the number of segments increases, and the phenomenon is more significant in the cross section (Fama-MacBeth (1973) regression) than within firm (firm fixed effects regression). We then create a single-segment dummy that equals 1 for single-segment firms, and interact the dummy with $\ln (\mathrm{CFV})$. Columns 4-6 show that the positive CFV-Q association is more pronounced for single-segment firms, and again, empirically more visible in the cross section than within firm. Overall, the results in Table 6 are consistent with Hypothesis 4.

\section{Alternative Explanations of the Positive CFV-Q Association}

There are several possible alternative explanations for the positive CFV-Q association. First, in real-options models, future volatility raises the value of waiting to invest when investments are irreversible (e.g., Dixit and Pindyck (1994)). Thus, real-options models imply a positive association between performance volatility and firm valuation. Second, for a levered firm, equity is equivalent to a call option on the underlying assets. Merton (1974) shows that higher volatility in the value of firm assets increases the value of firm equity. This leverage effect may also lead to a positive causal relation between performance volatility and firm valuation. Third, Pástor and Veronesi (2003) argue that small and young firms have higher valuation because of higher parameter uncertainty. As investors learn about a firm over time, both uncertainty and firm valuation decrease, resulting in a positive association between the two. Below, we examine whether these alternative mechanisms, rather than the mechanism in our theoretical model, drive our empirical findings.

\section{The Real-Options Effect}

We first examine the real-options effect from two angles. First, a key underlying condition for real-options models is that investments are partially or fully irreversible. If a firm can easily reverse its investments when future conditions turn out to be unfavorable, the value of waiting to invest will be low. Therefore, if the real-options effect drives our empirical findings, we should expect that the positive 
TABLE 6

Number of Business Segments and the CFV-Q Association

Table 6 reports results of Fama-MacBeth (1973), pooled ordinary least squares (OLS), and firm fixed effects regressions where the dependent variable is $\ln (\mathrm{Q})$. We study how correlations between cash flows across market segments affect the CFV-Q association. We include an interaction term between cash-flow volatility (In(CFV)) and the proxy for cash-flow correlation, N_SEG or SING_SEG. N_SEG is the number of business segments identified in Compustat segments files, and SING_SEG is a dummy equal to 1 for single-segment firms. We expect the cash-flow correlation to be higher for firms with fewer business segments. The coefficients of the interaction terms capture the difference in the CFV-Q association between single-segment and multisegment firms. An intercept is included but not reported. $R^{2}$ for firm fixed effects is the within $R^{2}$; for OLS the adjusted $R^{2}$; for Fama-MacBeth (1973) the average annual $R^{2}$. Standard errors in firm fixed effects and OLS regressions are clustered at the firm level and corrected for heteroskedasticity. Variables of interest are in bold, and $t$-values are reported in parentheses. ${ }^{*},{ }^{* *}$, and ${ }^{* * *}$ indicate significance at the $10 \%, 5 \%$, and $1 \%$ levels, respectively.

\begin{tabular}{|c|c|c|c|c|c|c|}
\hline & $\begin{array}{c}\text { Fama-MacBeth } \\
1 \\
\end{array}$ & $\begin{array}{c}\text { OLS } \\
2 \\
\end{array}$ & $\begin{array}{c}\begin{array}{c}\text { Firm } \\
\text { Fixed Effects } \\
3 \\
\end{array} \\
\end{array}$ & $\begin{array}{c}\text { Fama-MacBeth } \\
4 \\
\end{array}$ & $\begin{array}{c}\text { OLS } \\
5 \\
\end{array}$ & $\begin{array}{c}\text { Firm } \\
\text { Fixed Effects } \\
6 \\
\end{array}$ \\
\hline $\ln (\mathrm{CFV})$ & $\begin{array}{l}0.05^{\star \star \star} \\
(5.43)\end{array}$ & $\begin{array}{l}0.09^{\star \star *} \\
(7.22)\end{array}$ & $\begin{array}{l}0.11^{\star \star \star} \\
(8.55)\end{array}$ & $\begin{array}{c}0.00 \\
(0.01)\end{array}$ & $\begin{array}{l}0.05^{\star \star \star} \\
(3.93)\end{array}$ & $\begin{array}{l}0.07^{\star \star \star} \\
(6.74)\end{array}$ \\
\hline N_SEG $\times \ln (\mathrm{CFV})$ & $\begin{array}{l}-0.02^{\star \star \star} \\
(-5.72)\end{array}$ & $\begin{array}{l}-0.01^{\star \star \star} \\
(-3.20)\end{array}$ & $\begin{array}{l}-0.01^{\star \star} \\
(-2.39)\end{array}$ & & & \\
\hline N_SEG & $\begin{array}{l}-0.09^{\star \star \star} \\
(-7.60)\end{array}$ & $\begin{array}{l}-0.07^{\star \star *} \\
(-4.71)\end{array}$ & $\begin{array}{l}-0.04^{\star \star \star} \\
(-2.89)\end{array}$ & & & \\
\hline SING_SEG $\times \ln (\mathrm{CFV})$ & & & & $\begin{array}{l}0.03^{\star \star \star} \\
(4.39)\end{array}$ & $\begin{array}{l}0.03^{\star \star} \\
(2.04)\end{array}$ & $\begin{array}{l}0.02^{\star *} \\
(2.13)\end{array}$ \\
\hline SING_SEG & & & & $\begin{array}{l}0.19^{\star \star \star} \\
(6.97)\end{array}$ & $\begin{array}{l}0.17^{\star \star \star} \\
(3.46)\end{array}$ & $\begin{array}{l}0.12^{* * *} \\
(2.78)\end{array}$ \\
\hline In(ASSETS) & $\begin{array}{c}0.01^{*} \\
(2.06)\end{array}$ & $\begin{array}{l}0.02^{\star \star \star} \\
(5.45)\end{array}$ & $\begin{array}{c}-0.12^{\star \star \star} \\
(-14.78)\end{array}$ & $\begin{array}{c}0.01 \\
(1.72)\end{array}$ & $\begin{array}{l}0.02^{\star \star \star} \\
(4.98)\end{array}$ & $\begin{array}{l}-0.12^{\star \star \star} \\
(-14.82)\end{array}$ \\
\hline $\ln (A G E)$ & $\begin{array}{l}-0.03^{\star \star \star} \\
(-3.43)\end{array}$ & $\begin{array}{l}-0.03^{* * *} \\
(-2.75)\end{array}$ & 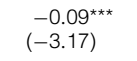 & 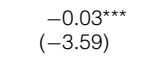 & $\begin{array}{l}-0.03^{\star \star \star} \\
(-2.74)\end{array}$ & $\begin{array}{l}-0.09^{\star \star \star} \\
(-3.04)\end{array}$ \\
\hline LEVERAGE & $\begin{array}{l}-0.12^{\star \star \star} \\
(-3.97)\end{array}$ & $\begin{array}{l}-0.11^{\star \star \star} \\
(-4.31)\end{array}$ & $\begin{array}{l}-0.07^{\star \star \star} \\
(-3.06)\end{array}$ & $\begin{array}{l}-0.12^{\star \star \star} \\
(-3.98)\end{array}$ & $\begin{array}{l}-0.11^{\star \star \star} \\
(-4.31)\end{array}$ & $\begin{array}{l}-0.07^{\star * \star} \\
(-3.07)\end{array}$ \\
\hline TANGIBILITY & $\begin{array}{l}-0.05^{\star \star} \\
(-2.11)\end{array}$ & $\begin{array}{c}0.03 \\
(0.98)\end{array}$ & $\begin{array}{c}0.05 \\
(0.94)\end{array}$ & $\begin{array}{l}-0.05^{\star \star} \\
(-2.09)\end{array}$ & $\begin{array}{c}0.04 \\
(1.03)\end{array}$ & $\begin{array}{c}0.05 \\
(0.96)\end{array}$ \\
\hline $\mathrm{ROA}$ & $\begin{array}{c}0.05 \\
(1.03)\end{array}$ & $\begin{array}{l}0.11^{\star \star \star} \\
(3.46)\end{array}$ & $\begin{array}{c}0.40^{* \star *} \\
(15.39)\end{array}$ & $\begin{array}{c}0.05 \\
(1.09)\end{array}$ & $\begin{array}{l}0.11^{\star \star \star \star} \\
(3.48)\end{array}$ & $\begin{array}{l}0.40^{\star \star \star \star} \\
(15.42)\end{array}$ \\
\hline $\mathrm{CASH}$ & $\begin{array}{c}1.13^{\star \star \star} \\
(23.00)\end{array}$ & $\begin{array}{c}0.98^{* * *} \\
(26.72)\end{array}$ & $\begin{array}{c}0.64^{\star \star \star} \\
(17.33)\end{array}$ & $\begin{array}{c}1.13^{\star \star \star} \\
(22.77)\end{array}$ & $\begin{array}{c}0.98^{\star \star \star} \\
(26.79)\end{array}$ & $\begin{array}{c}0.64^{* \star *} \\
(17.31)\end{array}$ \\
\hline SALES_GROWTH & $\begin{array}{c}0.55^{\star \star \star} \\
(19.93)\end{array}$ & $\begin{array}{c}0.48^{\star * \star} \\
(24.71)\end{array}$ & $\begin{array}{c}0.33^{\star \star \star} \\
(15.94)\end{array}$ & $\begin{array}{c}0.55^{\star \star \star} \\
(20.06)\end{array}$ & $\begin{array}{c}0.48^{\star \star \star} \\
(24.79)\end{array}$ & $\begin{array}{c}0.33^{\star * \star} \\
(15.98)\end{array}$ \\
\hline RD_CAPITAL & $\begin{array}{l}0.02^{\star \star \star} \\
(5.54)\end{array}$ & $\begin{array}{l}0.01^{\star \star \star} \\
(6.09)\end{array}$ & $\begin{array}{l}0.01^{\star \star \star} \\
(4.00)\end{array}$ & $\begin{array}{l}0.02^{\star \star \star} \\
(5.53)\end{array}$ & $\begin{array}{l}0.01^{\star \star \star} \\
(6.07)\end{array}$ & $\begin{array}{l}0.01^{* \star \star} \\
(3.98)\end{array}$ \\
\hline CAPEX & $\begin{array}{l}0.13^{\star \star \star} \\
(9.67)\end{array}$ & $\begin{array}{l}0.13^{\star * *} \\
(8.04)\end{array}$ & $\begin{array}{l}0.11^{* \star \star} \\
(7.34)\end{array}$ & $\begin{array}{l}0.13^{\star \star \star} \\
(9.59)\end{array}$ & $\begin{array}{l}0.13^{\star \star *} \\
(8.08)\end{array}$ & $\begin{array}{l}0.11^{* * *} \\
(7.31)\end{array}$ \\
\hline DIVIDEND & $\begin{array}{l}0.19^{\star \star \star} \\
(17.23)\end{array}$ & $\begin{array}{c}0.19^{\star \star \star} \\
(13.93)\end{array}$ & $\begin{array}{l}0.13^{\text {}} \\
(10.45)\end{array}$ & $\begin{array}{l}0.19^{\star \star \star} \\
(17.22)\end{array}$ & $\begin{array}{l}0.19^{\star \star \star} \\
(13.84)\end{array}$ & $\begin{array}{c}0.13^{\star \star \star} \\
(10.48)\end{array}$ \\
\hline $\begin{array}{l}\text { Firm fixed effects } \\
\text { Industry fixed effects } \\
\text { Year fixed effects }\end{array}$ & $\begin{array}{l}\text { No } \\
\text { No } \\
\text { No }\end{array}$ & $\begin{array}{l}\text { No } \\
\text { Yes } \\
\text { Yes }\end{array}$ & $\begin{array}{l}\text { Yes } \\
\text { No } \\
\text { Yes }\end{array}$ & $\begin{array}{l}\text { No } \\
\text { No } \\
\text { No }\end{array}$ & $\begin{array}{l}\text { No } \\
\text { Yes } \\
\text { Yes }\end{array}$ & $\begin{array}{l}\text { Yes } \\
\text { No } \\
\text { Yes }\end{array}$ \\
\hline $\begin{array}{l}\text { Obs. } \\
R^{2}\end{array}$ & $\begin{array}{c}70,455 \\
0.23 \\
\end{array}$ & $\begin{array}{c}70,455 \\
0.27 \\
\end{array}$ & $\begin{array}{c}70,455 \\
0.18 \\
\end{array}$ & $\begin{array}{c}70,455 \\
0.23 \\
\end{array}$ & $\begin{array}{c}70,455 \\
0.27 \\
\end{array}$ & $\begin{array}{c}70,455 \\
0.18 \\
\end{array}$ \\
\hline
\end{tabular}

CFV-Q association is concentrated among firms with more irreversible investments. Second, although investment irreversibility raises the value of waiting to invest, product market competition erodes the option value of waiting. In a more competitive market, the first-mover advantage becomes more important, and waiting to invest becomes a less desirable option (e.g., Mauer and Ott (1995), (2000), Back and Paulsen (2009), Morellec and Schürhoff (2011), and Li and Mauer (2016)). Therefore, if the real-options effect drives our empirical findings, the positive CFV-Q relation should be more pronounced in less competitive industries, where waiting to invest is strategically more affordable. To test these ideas, 
we run the CFV-Q regression (model (13)) on subsamples formed on investment irreversibility or product market competition.

Our first 2 irreversibility measures are based on the intuition in Dixit and Pindyck (1994) and Shleifer and Vishny (1992) that a firm's investment irreversibility is higher when the firm's cash flows or returns correlate more closely with its industry peers. Higher correlation makes it more difficult for the firm to divest following a negative shock because its industry peers likely have experienced the same negative shock and therefore are unwilling or unable to purchase the firm's assets and provide liquidity. To measure this correlation, we estimate the following 2-factor model:

$$
R_{i t}=\beta_{0}+\beta_{1} \times R_{m k t, t}+\beta_{2} \times R_{\text {ind,t }}+\epsilon_{i t},
$$

where $R_{i t}$ is firm $i$ 's stock return in month $t, R_{m k t, t}$ is the CRSP value-weighted market return, and $R_{\text {ind, } t}$ is the value-weighted return of firm $i$ 's industry (excluding firm $i)$. A firm with a higher industry beta $\left(\beta_{2}\right)$ or a lower idiosyncratic variance ratio $\left(\sigma^{2}\left(\epsilon_{i t}\right) / \sigma^{2}\left(R_{i t}\right)\right)$ should have higher correlation with its industry peers, and thus higher irreversibility. ${ }^{6}$ We classify industries by 3-digit SIC codes and use rolling 60-month returns to estimate model (16). We obtain similar results when alternatively classifying industries using 2-digit SIC codes or Fama and French (1997) 48-industry definition, or when using returns of the full sample period rather than rolling 60-month returns.

We identify four other proxies for investment irreversibility following the empirical literature of real options (e.g., Panousi and Papanikolaou (2012), Badertscher et al. (2013)). First, if a firm's investment is from new capital goods rather than used capital goods, irreversibility is higher. We obtain the industry ratio of new capital goods to total capital goods from the Census survey data. Second, if a firm's capital depreciates quickly, investment irreversibility is higher. We measure the depreciation speed by the industry average depreciation rate. Third, if a firm is unable to easily sell its capital, irreversibility is high. We compute the industry average ratio of PPE sales to total PPE. Lower PPE sales ratio indicates higher irreversibility. Fourth, an active merger and acquisition (M\&A) market indicates higher liquidity of capital assets and thus higher reversibility. We compute the industry liquidity ratio as total M\&A value to total book assets value (Schlingemann, Stulz, and Walkling (2002)). Lower liquidity indicates higher irreversibility. The Appendix provides details on these proxies. We use 3-digit SIC codes to define industries. Alternative classifications using 2-digit SIC codes or Fama and French (1997) 48 industries lead to similar findings. ${ }^{7}$

In Table 7, we split our sample into high- and low-irreversibility subsamples by the median of each irreversibility measure and compare the CFV-Q relation

\footnotetext{
${ }^{6} \mathrm{We}$ are very grateful to the referee for suggesting the test and these two measures of irreversibility.

${ }^{7}$ Except for the first measure that uses survey data from 1998, for the other three measures we take the average of annual values between 1991 and 1999, and apply this average to the full sample period as the measure of irreversibility. This approach has two benefits. First, taking the average over a few years reduces the annual volatility in these measures and hence obtains a more normalized gauge of irreversibility. Second, using the average over the first few years of the sample period maintains some out-of-sample exogeneity of these measures with respect to the data after 1999. Panousi and Papanikolaou (2012) use a similar approach when constructing some of their irreversibility measures. When alternatively using the annual values or the full sample averages, we obtain similar results.
} 
TABLE 7

Robustness: Irreversibility and the CFV-Q Association

Table 7 reports results of firm fixed effects regressions where the dependent variable is $\ln (\mathrm{Q})$. The regressions are to examine whether investment irreversibility affects the CFV-Q association. Irreversibility should increase the real-options value of waiting to invest. Thus, if the real-options effect is driving the positive CFV- $Q$ association, the positive CFV- $Q$ association should be concentrated among firms with high irreversibility. The sample is split by the median value of the 6 irreversibility measures. The column headings indicate the measure used and whether the subsample of firms are of low or high irreversibility. An intercept is included but not reported. $R^{2}$ is the within $R^{2}$. Variables of interest are in bold, and $t$-values are reported in parentheses. *, **, and ${ }^{* * *}$ indicate significance at the $10 \%, 5 \%$, and $1 \%$ levels, respectively.

$\ln (\mathrm{CFV})$

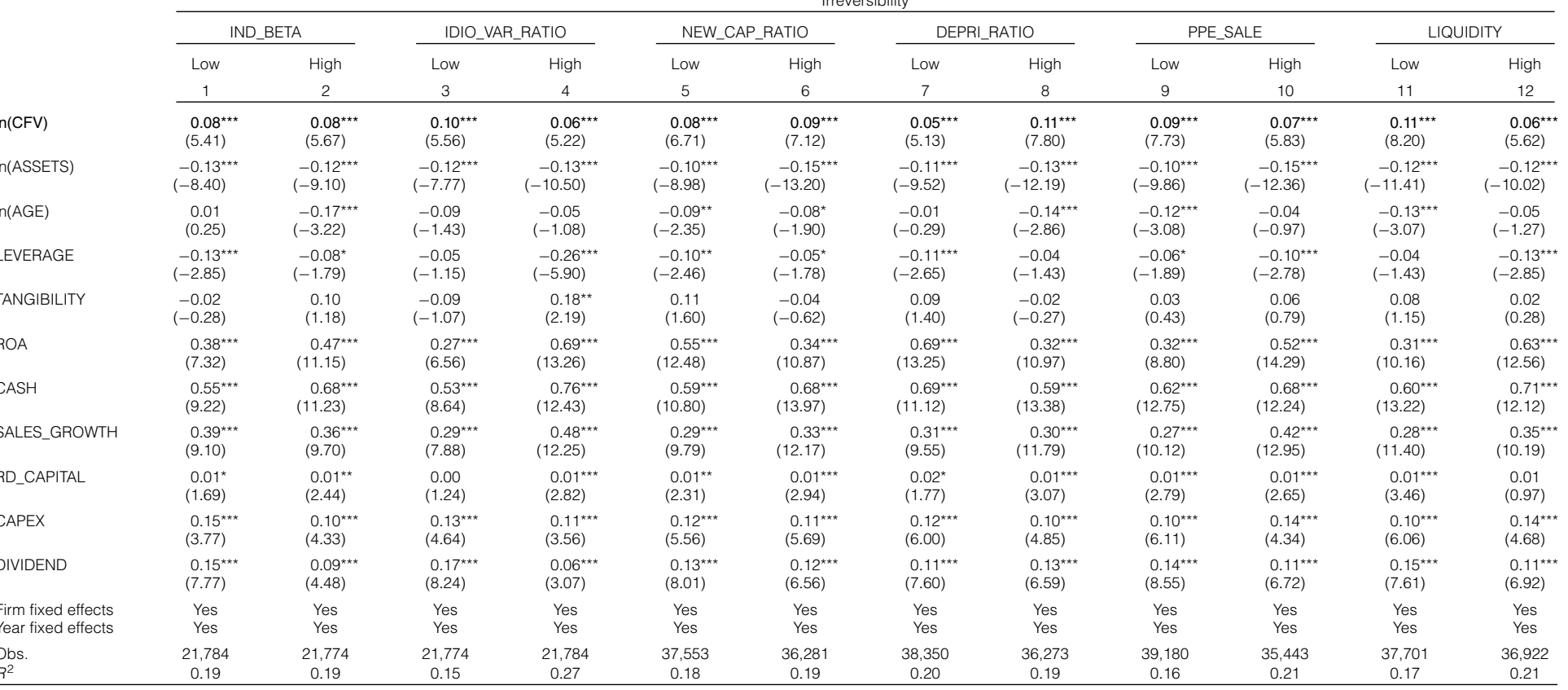


across the subsamples. The column headings indicate the measure used and the degree of irreversibility. All odd-numbered regressions use observations with low irreversibility, and all even-numbered regressions use those with high irreversibility. The CFV-Q relation is similar between firms with high or low industry beta. Out of the other 5 irreversibility measures, 3 measures actually show a larger CFV coefficient for low-irreversibility firms (see columns 3, 9, and 11), the opposite of what the real-options effect predicts. ${ }^{8}$

We use 2 measures of product market competition: the HHI and product market fluidity constructed by Hoberg et al. (2014). ${ }^{9}$ Lower HHI indicates more intense competition. Fluidity is defined as the dot product between the words used in a firm's business description from 10-K filings and the change in the words used by its rivals. When rivals change their business descriptions to be more similar to the firm's, overlap in word usage increases and fluidity increases. Thus, higher fluidity reflects more intense product market threats from rivals. Fluidity is available from 1997 to 2011. In Table 8, we split the sample by HHI or fluidity median. Firms with high HHI or low fluidity (columns 1 and 3) face less intense competition and, under the real-options explanation, should have a more pronounced CFV-Q relation. Rather, results suggest that the CFV-Q relation is similar between firms facing high competition and firms facing low competition.

To summarize, the positive CFV-Q association is not concentrated among firms with high investment irreversibility or facing low competitive threats, and therefore is unlikely to be driven by the real-options effect.

\section{The Leverage Effect}

We examine the leverage effect in Merton's (1974) option-pricing theory by splitting our sample into firms with zero debt versus firms with high financial leverage, defined as those in the top third of total financial leverage in a given year. Note that the leverage effect exists only if the firm is levered. We run model (13) using subsamples with zero or high leverage and report the results in columns 1 and 2 of Table 9. The positive CFV-Q association obtains in both zero-leverage and high-leverage subsamples, suggesting that our findings are not driven by the leverage effect.

\section{The Uncertainty-and-Learning Effect}

To examine the uncertainty-and-learning effect of Pástor and Veronesi (2003), we split our sample into high- and low-uncertainty subsamples. The uncertainty-and-learning effect implies that the positive CFV-Q association is more pronounced for high-uncertainty firms. A widely used measure of uncertainty is analyst forecast dispersion (e.g., Imhoff and Lobo (1992), Johnson

\footnotetext{
${ }^{8}$ In columns $5-12$ of Table 7 , the numbers of observations in each pair of split samples are not exactly balanced because these measures are at the industry level. Split samples using firm-level measures are more balanced, for example, in columns 1-4. Columns 1-4 have fewer observations because we use rolling 60-month returns to calculate the 2 measures, which means we have to discard up to 5 annual observations for each firm.

${ }^{9}$ For the tabulated results, HHI is calculated at the 3-digit SIC level, and the results are robust to denning industries with 2-digit SIC codes or Fama-French (1997) 48 industries. We would like to thank Jerry Hoberg and Gordon Phillips for generously sharing the fluidity data on their Web site (http://hobergphillips.usc.edu).
} 
TABLE 8

Robustness: Product Market Competition and the CFV-Q Association

\begin{tabular}{|c|c|c|c|c|}
\hline \multicolumn{5}{|c|}{$\begin{array}{l}\text { Table } 8 \text { reports results of firm fixed effects regressions where the dependent variab } \\
\text { examine whether product market competition affects the CFV-Q association. More } \\
\text { the real-options value of waiting to invest. Thus, if the real-options effect is driving th } \\
\text { positive CFV-Q association should be concentrated among firms with less intense } \\
\text { by the median value of the Herfindahl-Hirschman Index (HHI) or product market } f \text { l } \\
\text { indicates more intense competition. The column headings indicate the measure us } \\
\text { firms face low or high competition intensity. An intercept is included but not reporte } \\
\text { interest are in bold, and } t \text {-values are reported in parentheses. }{ }^{*},{ }^{* *} \text {, and }{ }^{* * *} \text { indicate si } \\
\text { levels, respectively. } \\
\text { Competition }\end{array}$} \\
\hline & \multicolumn{2}{|c|}{$\mathrm{HHI}$} & \multicolumn{2}{|c|}{ Fluidity } \\
\hline & Low & High & Low & High \\
\hline & 1 & 2 & 3 & 4 \\
\hline $\ln (\mathrm{CFV})$ & $\begin{array}{l}0.08^{\star \star \star} \\
(6.47)\end{array}$ & $\begin{array}{l}0.09^{\star \star \star} \\
(7.14)\end{array}$ & $\begin{array}{l}0.10^{\star \star \star} \\
(6.09)\end{array}$ & $\begin{array}{l}0.10^{\star \star \star} \\
(6.18)\end{array}$ \\
\hline In(ASSETS) & $\begin{array}{l}-0.11^{\star * *} \\
(-9.32)\end{array}$ & $\begin{array}{l}-0.13^{\star \star \star} \\
(-12.45)\end{array}$ & $\begin{array}{l}-0.12^{\star \star \star} \\
(-7.30)\end{array}$ & $\begin{array}{l}-0.16^{\star \star \star} \\
(-12.01)\end{array}$ \\
\hline $\ln (A G E)$ & $\begin{array}{l}-0.09^{* *} \\
(-2.34)\end{array}$ & $\begin{array}{l}-0.09^{\star *} \\
(-1.97)\end{array}$ & $\begin{array}{l}0.10^{\star \star} \\
(1.99)\end{array}$ & $\begin{array}{l}-0.05 \\
(-0.78)\end{array}$ \\
\hline LEVERAGE & $\begin{array}{l}-0.10^{\star \star} \\
(-2.54)\end{array}$ & $\begin{array}{l}-0.03 \\
(-0.88)\end{array}$ & $\begin{array}{l}-0.11^{*} \\
(-1.86)\end{array}$ & $\begin{array}{l}-0.02 \\
(-0.55)\end{array}$ \\
\hline TANGIBILITY & $\begin{array}{c}0.02 \\
(0.25)\end{array}$ & $\begin{array}{c}0.04 \\
(0.66)\end{array}$ & $\begin{array}{c}0.08 \\
(0.95)\end{array}$ & $\begin{array}{c}0.05 \\
(0.55)\end{array}$ \\
\hline $\mathrm{ROA}$ & $\begin{array}{l}0.51^{\star \star *} \\
(10.02)\end{array}$ & $\begin{array}{c}0.37^{\star \star *} \\
(12.82)\end{array}$ & $\begin{array}{l}0.70^{\star \star \star} \\
(11.25)\end{array}$ & $\begin{array}{l}0.28^{\star \star \star} \\
(8.80)\end{array}$ \\
\hline CASH & $\begin{array}{l}0.61^{\star \star \star} \\
(9.85)\end{array}$ & $\begin{array}{c}0.64^{\star \star \star} \\
(14.74)\end{array}$ & $\begin{array}{l}0.63^{\star \star \star} \\
(9.50)\end{array}$ & $\begin{array}{c}0.59^{\star \star \star} \\
(11.26)\end{array}$ \\
\hline SALES_GROWTH & $\begin{array}{l}0.32^{* * *} \\
(9.15)\end{array}$ & $\begin{array}{c}0.30^{* * *} \\
(12.22)\end{array}$ & $\begin{array}{l}0.47^{\star \star \star} \\
(8.91)\end{array}$ & $\begin{array}{l}0.24^{\star \star \star} \\
(8.80)\end{array}$ \\
\hline RD_CAPITAL & $\begin{array}{c}0.00 \\
(0.40)\end{array}$ & $\begin{array}{l}0.01^{* \star *} \\
(3.43)\end{array}$ & $\begin{array}{c}0.00 \\
(0.26)\end{array}$ & $\begin{array}{l}0.01^{\star \star \star} \\
(2.67)\end{array}$ \\
\hline CAPEX & $\begin{array}{l}0.15^{\star \star \star} \\
(4.37)\end{array}$ & $\begin{array}{l}0.10^{\star \star \star} \\
(6.31)\end{array}$ & $\begin{array}{l}0.16^{\star \star \star} \\
(2.90)\end{array}$ & $\begin{array}{l}0.09^{\star \star \star} \\
(4.53)\end{array}$ \\
\hline DIVIDEND & $\begin{array}{l}0.11^{* * *} \\
(7.39)\end{array}$ & $\begin{array}{l}0.14^{* \star *} \\
(7.30)\end{array}$ & $\begin{array}{l}0.13^{\star \star \star} \\
(7.30)\end{array}$ & $\begin{array}{l}0.07^{\star \star \star} \\
(3.00)\end{array}$ \\
\hline $\begin{array}{l}\text { Firm fixed effects } \\
\text { Year fixed effects }\end{array}$ & $\begin{array}{l}\text { Yes } \\
\text { Yes }\end{array}$ & $\begin{array}{l}\text { Yes } \\
\text { Yes }\end{array}$ & $\begin{array}{l}\text { Yes } \\
\text { Yes }\end{array}$ & $\begin{array}{l}\text { Yes } \\
\text { Yes }\end{array}$ \\
\hline $\begin{array}{l}\text { Obs. } \\
R^{2}\end{array}$ & $\begin{array}{c}37,116 \\
0.18\end{array}$ & $\begin{array}{c}37,137 \\
0.19\end{array}$ & $\begin{array}{c}23,158 \\
0.25\end{array}$ & $\begin{array}{c}23,158 \\
0.20 \\
\end{array}$ \\
\hline
\end{tabular}

(2004), and Zhang (2006)). We measure dispersion as the standard deviation of analyst forecasts for next year's earnings and then scaled by stock price. Higher dispersion should indicate higher uncertainty about firm future profitability. We split the sample each year by the dispersion median and run regressions on the subsamples in columns 3 and 4. The positive CFV-Q association obtains in both low- and high-dispersion subsamples, and the association is actually slightly larger in the low-dispersion subsample, the opposite of what the learning explanation predicts. In untabulated tests, we alternatively scale the dispersion by mean or median analyst forecast. The results are similar.

CFV does not necessarily mean cash-flow uncertainty, but to the extent that CFV is positively correlated with uncertainty, we should expect that under the uncertainty-and-learning explanation, the positive CFV-Q association is more pronounced for high-CFV firms. ${ }^{10}$ We split the sample firms each year by the CFV

\footnotetext{
${ }^{10}$ Previous studies also use CFV as a measure of uncertainty (e.g., Zhang (2006)).
} 
TABLE 9

Robustness: Leverage/Uncertainty and the CFV-Q Association

\begin{tabular}{|c|c|c|c|c|c|c|}
\hline \multicolumn{7}{|c|}{$\begin{array}{l}\text { Table } 9 \text { reports results of firm fixed effects re } \\
\text { examine alternative explanations for the CFV- } \\
\text { column headings. First, if the positive CFV-Q a } \\
\text { (Merton (1974)), the positive CFV-Q associati } \\
\text { runs on zero-debt firms and } 2 \text { on high-levere } \\
Q \text { association is driven by the uncertainty-an } \\
\text { association should be much more pronouncec } \\
\text { learning effect. LOW_DISP (HIGH_DISP) firms } \\
\text { LOW_CFV (HIGH_CFV) firms are those with be } \\
R^{2} \text { is the within } R^{2} \text {. Standard errors are clustere } \\
\text { are in bold, and } t \text {-values are reported in paren } \\
\text { respectively. }\end{array}$} \\
\hline & Zero Debt & High Debt & LOW_DISP & HIGH_DISP & LOW_CFV & HIGH_CFV \\
\hline & 1 & 2 & 3 & 4 & 5 & 6 \\
\hline $\ln (\mathrm{CFV})$ & $\begin{array}{l}0.05^{\star \star} \\
(2.18)\end{array}$ & $\begin{array}{l}0.05^{\star \star \star} \\
(4.21)\end{array}$ & $\begin{array}{l}0.07^{\star \star \star} \\
(5.74)\end{array}$ & $\begin{array}{l}0.06^{\star \star \star} \\
(5.53)\end{array}$ & $\begin{array}{l}0.09^{\star \star \star} \\
(7.14)\end{array}$ & $\begin{array}{l}0.10^{\star * *} \\
(6.38)\end{array}$ \\
\hline In(ASSETS) & $\begin{array}{l}-0.12^{\star \star \star} \\
(-4.69)\end{array}$ & $\begin{array}{l}-0.16^{\star \star \star} \\
(-11.24)\end{array}$ & $\begin{array}{l}-0.16^{\star \star \star} \\
(-14.57)\end{array}$ & $\begin{array}{l}-0.16^{\star * *} \\
(-13.71)\end{array}$ & $\begin{array}{l}-0.10^{\star \star \star} \\
(-9.19)\end{array}$ & $\begin{array}{l}-0.13^{\star \star \star *} \\
(-11.49)\end{array}$ \\
\hline $\ln (A G E)$ & $\begin{array}{l}-0.36^{* * *} \\
(-3.57)\end{array}$ & $\begin{array}{c}0.01 \\
(0.12)\end{array}$ & $\begin{array}{l}0.08^{* *} \\
(2.09)\end{array}$ & $\begin{array}{l}-0.05 \\
(-1.40)\end{array}$ & $\begin{array}{l}0.07^{\star *} \\
(2.04)\end{array}$ & $\begin{array}{l}-0.23^{\text {*** }} \\
(-4.85)\end{array}$ \\
\hline LEVERAGE & $\begin{array}{l}0.35^{\star *} \\
(2.51)\end{array}$ & $\begin{array}{c}0.03 \\
(1.02)\end{array}$ & 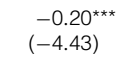 & $\begin{array}{l}-0.00 \\
(-0.10)\end{array}$ & $\begin{array}{l}-0.29^{\star \star \star} \\
(-7.56)\end{array}$ & $\begin{array}{l}-0.00 \\
(-0.11)\end{array}$ \\
\hline TANGIBILITY & $\begin{array}{l}-0.08 \\
(-0.46)\end{array}$ & $\begin{array}{r}0.13^{*} \\
(1.87)\end{array}$ & $\begin{array}{c}0.14^{*} \\
(1.95)\end{array}$ & $\begin{array}{c}0.07 \\
(1.19)\end{array}$ & $\begin{array}{l}0.15^{\star \star} \\
(2.41)\end{array}$ & $\begin{array}{c}0.00 \\
(0.05)\end{array}$ \\
\hline $\mathrm{ROA}$ & $\begin{array}{l}0.49^{\star \star \star} \\
(9.44)\end{array}$ & $\begin{array}{l}0.27^{\star \star *} \\
(6.93)\end{array}$ & $\begin{array}{l}1.81^{\star \star \star} \\
(15.46)\end{array}$ & $\begin{array}{c}0.40^{\star \star \star} \\
(10.87)\end{array}$ & $\begin{array}{l}0.93^{\text {*** }} \\
(17.08)\end{array}$ & $\begin{array}{l}0.30^{\star \star *} \\
(10.55)\end{array}$ \\
\hline $\mathrm{CASH}$ & $\begin{array}{l}0.42^{\star \star \star} \\
(5.79)\end{array}$ & $\begin{array}{l}0.49^{\star \star \star} \\
(6.02)\end{array}$ & $\begin{array}{c}0.60^{\star \star \star} \\
(11.72)\end{array}$ & $\begin{array}{c}0.59^{\star \star \star} \\
(11.39)\end{array}$ & $\begin{array}{c}0.63^{\star \star \star} \\
(12.61)\end{array}$ & $\begin{array}{l}0.67^{\star \star \star} \\
(14.62)\end{array}$ \\
\hline SALES_GROWTH & $\begin{array}{l}0.40^{* * *} \\
(7.92)\end{array}$ & $\begin{array}{l}0.20^{\star \star *} \\
(6.16)\end{array}$ & $\begin{array}{l}0.47^{* \star *} \\
(12.48)\end{array}$ & $\begin{array}{l}0.20^{* * *} \\
(7.35)\end{array}$ & $\begin{array}{c}0.37^{* * *} \\
(11.74)\end{array}$ & $\begin{array}{l}0.28^{\star \star *} \\
(11.30)\end{array}$ \\
\hline RD_CAPITAL & $\begin{array}{l}0.01^{\star \star \star} \\
(4.16)\end{array}$ & $\begin{array}{c}0.00 \\
(1.06)\end{array}$ & $\begin{array}{r}0.02^{*} \\
(1.94)\end{array}$ & $\begin{array}{c}0.00 \\
(1.56)\end{array}$ & $\begin{array}{c}0.00 \\
(0.15)\end{array}$ & $\begin{array}{l}0.01^{\star * *} \\
(3.42)\end{array}$ \\
\hline CAPEX & $\begin{array}{l}0.06^{* *} \\
(2.24)\end{array}$ & $\begin{array}{l}0.11^{\star \star *} \\
(4.65)\end{array}$ & $\begin{array}{l}0.15^{\star \star \star} \\
(3.40)\end{array}$ & $\begin{array}{l}0.06^{* * *} \\
(3.42)\end{array}$ & $\begin{array}{l}0.13^{\star * *} \\
(5.54)\end{array}$ & 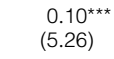 \\
\hline DIVIDEND & $\begin{array}{l}0.14^{\star * *} \\
(3.77)\end{array}$ & $\begin{array}{l}0.12^{\star \star \star} \\
(6.64)\end{array}$ & $\begin{array}{l}0.04^{\star *} \\
(2.14)\end{array}$ & $\begin{array}{l}0.09^{* * *} \\
(6.02)\end{array}$ & $\begin{array}{l}0.08^{\star \star \star} \\
(5.73)\end{array}$ & $\begin{array}{l}0.15^{\text {*** }} \\
(8.32)\end{array}$ \\
\hline $\begin{array}{l}\text { Firm fixed effects } \\
\text { Year fixed effects }\end{array}$ & $\begin{array}{l}\text { Yes } \\
\text { Yes }\end{array}$ & $\begin{array}{l}\text { Yes } \\
\text { Yes }\end{array}$ & $\begin{array}{l}\text { Yes } \\
\text { Yes }\end{array}$ & $\begin{array}{l}\text { Yes } \\
\text { Yes }\end{array}$ & $\begin{array}{l}\text { Yes } \\
\text { Yes }\end{array}$ & $\begin{array}{l}\text { Yes } \\
\text { Yes }\end{array}$ \\
\hline $\begin{array}{l}\text { Obs. } \\
R^{2}\end{array}$ & $\begin{array}{c}10,564 \\
0.24\end{array}$ & $\begin{array}{c}24,727 \\
0.14\end{array}$ & $\begin{array}{c}22,446 \\
0.33\end{array}$ & $\begin{array}{c}22,420 \\
0.23\end{array}$ & $\begin{array}{c}37,319 \\
0.23\end{array}$ & $\begin{array}{c}37,304 \\
0.17\end{array}$ \\
\hline
\end{tabular}

median and show the regression results of low- and high-CFV firms in columns 5 and 6. The positive CFV-Q association obtains in both low- and high-CFV firms with similar magnitude. Overall, these results suggest that our main findings cannot be explained by uncertainty and learning.

\section{E. Do Investors Value Smooth Performance?}

Froot et al. (1993) show that if volatile cash flows hinder a firm's ability to readily capture positive NPV projects, firm valuation will be diminished. Thus, corporate risk management can enhance firm valuation by reducing CFV. Consistent with this view, Rountree et al. (2008) provide empirical evidence of a negative CFV-Q association. They measure CFV as the standard deviation of cash flow per share, without standardizing per share size across firms. Thus, in the regression of $\mathrm{Q}$ on $\mathrm{CFV}$, although $\mathrm{Q}$ is a ratio and can be compared across firms, their measure of CFV is largely a function of a firm's per share size. For example, Berkshire 
Hathaway has the largest per share cash-flow standard deviation in our sample mainly because Berkshire Hathaway has by far the largest per share size, but it does not mean that Berkshire Hathaway has the highest CFV. Including total firm size as a control variable in the regression does not correct the problem because even for firms similar in total size, their per share sizes can differ dramatically.

In untabulated tests, we are able to closely replicate the main results of Rountree et al. (2008). For example, in their baseline regression (their regression 3 in Table 4), the coefficient estimate on per share CFV is -0.150 ( $p$-value $<0.001$ ), and the adjusted $R^{2}$ is 0.270 . Our replication produces a coefficient estimate of -0.144 ( $p$-value $<0.001$ ) and an adjusted $R^{2}$ of 0.267 . However, once we replace per share CFV with the volatility of cash-flow-to-assets ratio, the coefficient estimate becomes positive and highly significant ( $p$-value $<0.001$ ).

Furthermore, in Froot et al. (1993), if external financing is constrained, volatile cash flows are undesirable and risk management that reduces CFV can be value enhancing. This implies that the CFV-Q relation should be less positive or even negative when financial constraints are more binding. However, as shown in Table 4, the CFV-Q association is stronger for small and young firms. Because small and young firms are widely viewed as more financially constrained (see, e.g., Hadlock and Pierce (2010)), our results indicate that even if risk management that reduces CFV could enhance firm valuation as in Froot et al. (1993), the effect does not outweigh the positive CFV-Q association documented in our model.

\section{F. Additional Robustness Checks \\ 1. Two-Way Clustering}

In all the reported regression tests, we correct regression standard errors for firm-level clustering because there is likely nontrivial autocorrelation at the firm level. Because our interpretation relies on firm fixed effects specifications and includes year dummies in all regressions, correlation across firms in each year is unlikely to significantly bias our statistical significance. ${ }^{11}$ Nevertheless, we rerun all tests and adjust the standard errors for both firm and year clustering. The $t$-statistics are somewhat reduced for the OLS regressions, but most of them remain above the conventional threshold to conclude statistical significance. The $t$-statistics actually increase for most firm fixed effects regressions. In sum, additional clustering by year does not change the interpretation of results.

\section{Cross-Sectional Tests}

Although our theoretical model is set up with a within-firm or time-series structure, the model's predictions are also generalizable to the cross section. To the extent that a cross-sectional empirical test adequately controls for firm heterogeneity, our empirical results from firm fixed effects specifications should also

\footnotetext{
${ }^{11}$ Petersen (2009) suggests, "One way empirical finance researchers can address two sources of correlation is to parametrically estimate one of the dimensions (e.g., by including dummy variables). Since many panel data sets have more firms than years, a common approach is to include dummy variables for each time period (to absorb the time effect) and then cluster by firm" (p. 475). To implement this suggestion, in both OLS and firm fixed effects specifications, we include year dummies and cluster by firm.
} 
obtain in the cross section. We so far have reported OLS specifications that use both within-firm and cross-firm variations when estimating the coefficients. For all the tabulated tests, we also run the Fama-MacBeth (1973) specification that derives its estimates solely from cross-sectional variations. We find mostly consistent results with those tabulated. Some coefficients are larger than firm fixed effects estimates; some are smaller. But the interpretations of the findings do not change.

\section{Controlling for Autocorrelation}

Our CFV measure is computed using rolling 5-year quarterly data. We have adjusted the standard errors to correct potential bias that overlapping data may have caused on our statistical significance. To examine whether our coefficient estimates are biased by overlapping data, we rerun all regressions with only the 5 years of data that are not overlapping: 1991, 1996, 2001, 2006, and 2011. Even with substantially fewer data points, we obtain mostly consistent results. For example, for our baseline regression of $\ln (\mathrm{Q})$ on $\ln (\mathrm{CFV})$ in column 4 of Table 4 , the coefficient estimate on $\ln (\mathrm{CFV})$ is 0.09 ( $t$-statistic $=7.18)$, compared to the tabulated coefficient of 0.08 ( $t$-statistic $=9.90)$. A few regressions lose significance, mostly firm fixed effects regressions with interaction terms. We suspect that the smaller number of years renders firm fixed effects a low-power specification. In sum, our main findings are not significantly biased by the overlapping construction in our CFV measure.

\section{Alternative Definition of Firm Age}

In reported regressions, we use $\ln (\mathrm{AGE})$. We alternatively follow Pástor and Veronesi (2003) and transform firm age as AGE2 $=-1 /(1+$ AGE). The transformation is to capture the nonlinear relation between firm age and CFV or Q. For example, CFV and Q drop faster in a firm's early years, which we call "growth periods," and slower as the firm matures. The natural logarithm value of firm age also captures this nonlinear relation. The correlation between $\ln (\mathrm{AGE})$ and AGE2 in our sample is 0.97. We obtain similar results when we use AGE2 in the regressions.

\section{Conclusion}

Younger and smaller firms have higher performance volatility and higher, rather than lower, firm valuation. We provide a rational explanation to this seemingly puzzling empirical regularity. We show through a theoretical model that as a firm grows older and larger, both its $\mathrm{CFV}$ and $\mathrm{Q}$ decrease. The simultaneous drop in CFV and Q leads to a positive association between CFV and Q. We empirically document the positive association within firm and across firms. Also as predicted by the model, we document that the positive association between CFV and $\mathrm{Q}$ is more pronounced for firms that are young (small), have larger growth opportunities, and have higher cash-flow correlation across segments. We show that our explanation of the positive CFV-Q association is different from the explanations offered in real-options models (e.g., McDonald and Siegel (1986)), option-valuation models (e.g., Merton (1974)), or uncertainty-and-learning models (Pástor and Veronesi (2003)). Compared to extant studies, our theoretical 
framework is able to explain the positive CFV-Q association for a larger set of firms. Although we use $\mathrm{Q}$ as the valuation measure in our analysis, it is straightforward to generalize our model implications to other popular valuation metrics, such as the price-to-earnings ratio.

\section{Appendix. Variable Definitions}

\section{Variables of Main Interest}

$\mathrm{Q}$ The market value of assets to book value of assets, and $\mathrm{Q}=\left(\operatorname{prcc}_{-} f \times c s h o+d l t t\right) / a t$.

CFV The standard deviation of quarterly cash flow over book assets (=oancfy/atq) for the last 20 quarters, requiring $\geq 8$ quarters of data. oancfy is reported as year-to-date value in Compustat. We adjust it to quarterly value before scaling by atq.

\section{Explanatory Variables}

ASSETS Total assets, at, measured in millions of CPI-adjusted 2004 U.S. dollars. In our regressions, we mostly use the natural logarithm value, $\ln$ (ASSETS).

AGE The number of years a firm has appeared in Compustat. In our regressions, we mostly use the natural logarithm value, $\ln (\mathrm{AGE})$.

ROA Income before extraordinary items/total assets (e.g., ib/at).

LEVERAGE Total liabilities/total assets (e.g., $1-(c e q / a t)$ ).

TANGIBILITY Property, plant, and equipment (PP\&E)/total assets (e.g., ppent/at).

CASH The level of cash holdings divided by total assets (e.g., che/at).

SALES_GROWTH Compound annual growth rate of annual sales (sale) over the past 5 years.

RD_CAPITAL Research and development (R\&D) capital (Chan, Lakonishok, and Sougiannis (2001)), defined as the sum of R\&D-to-sales ratios ( $x r d / s a l e)$ in the past 5 years, using a $20 \%$ depreciation rate.

CAPEX Capital expenditures divided by sales (e.g., capx/sale).

DIVIDEND Dummy variable that equals 1 for firms that pay dividends (e.g., $d v c>0$ ).

N_SEG Number of business segments in the Compustat Segment files.

SING_SEG Dummy variable that equals 1 for firms with a single business segment.

DISP The standard deviation of analyst forecasts for next year's earnings per share scaled by the stock price.

\section{Indicators of Growth Opportunities}

S_GROWTH Dummy variable that equals 1 for firms with above-median sales growth.

D_PATENT Dummy variable that equals 1 for firms with positive number of patents.

RDC Dummy variable that equals 1 for firms with above-median R\&D capital.

\section{Proxies for Product Market Competition}

HHI The Herfindahl-Hirschman Index, measuring industry concentration of sales.

FLUIDITY The product market fluidity measure by Hoberg, Phillips, and Prabhala (2014). Based on textual analysis of a firm's 10-K filings, fluidity is the dot product between the words used in a firm's business description and the change in the words used by its rivals. 


\section{Proxies for Investment Irreversibility}

IND_BETA Firm industry stock beta $\left(\beta_{2}\right.$ in model (16)).

IDIO_VAR_RATIO The ratio of firm idiosyncratic stock return variance to total variance $\left(\sigma^{2}\left(\epsilon_{i t}\right) / \sigma^{2}\left(R_{i t}\right)\right.$, based on the estimation in model (16).

NEW_CAP_RATIO The industry ratio of new capital goods to total capital goods from the 1998 Census survey data.

DEPRI_RATIO The industry average depreciation rate (e.g., $d p / p p e n t)$.

PPE_SALE The industry average ratio of PP\&E sales to total PP\&E (e.g., sppe/ppent).

LIQUIDITY The industry liquidity ratio computed as industry total mergers and acquisitions (M\&A) value to total book assets value (Schlingemann, Stulz, and Walkling (2002)).

\section{References}

Adam, T.; S. Dasgupta; and S. Titman. "Financial Constraints, Competition, and Hedging in Industry Equilibrium." Journal of Finance, 62 (2007), 2445-2473.

Allayannis, G., and J. Weston. "The Use of Foreign Currency Derivatives and Firm Market Value." Review of Financial Studies, 14 (2001), 243-276.

Back, K., and D. Paulsen. "Open-Loop Equilibria and Perfect Competition in Option Exercise Games." Review of Financial Studies, 22 (2009), 4531-4552.

Badertscher, B.; N. Shroff; and H. D. White. "Externalities of Public Firm Presence: Evidence from Private Firms' Investment Decisions." Journal of Financial Economics, 109 (2013), 682-706.

Chan, L. K. C.; J. Lakonishok; and T. Sougiannis. "The Stock Market Valuation of Research and Development Expenditures." Journal of Finance, 56 (2001), 2431-2456.

Demsetz, H., and K. Lehn. "The Structure of Corporate Ownership: Causes and Consequences." Journal of Political Economy, 93 (1985), 1155-1177.

Dickinson, V. "Cash Flow Patterns as a Proxy for Firm Life Cycle." Accounting Review, 86 (2011), 1969-1994.

Dixit, A. K., and R. S. Pindyck. Investment under Uncertainty. Princeton, NJ: Princeton University Press (1994).

Fama, E. F., and K. R. French. "Industry Costs of Equity." Journal of Financial Economics, 43 (1997), $153-193$.

Fama, E. F., and J. D. MacBeth. "Risk, Return, and Equilibrium: Empirical Tests." Journal of Political Economy, 81 (1973), 607-636.

Froot, K. A.; D. S. Scharfstein; and J. C. Stein. "Risk Management: Coordinating Corporate Investment and Financing Policies." Journal of Finance, 48 (1993), 1629-1658.

Gompers, P. A.; J. L. Ishii; and A. Metrick. "Corporate Governance and Equity Prices." Quarterly Journal of Economics, 118 (2003), 107-155.

Gort, M., and S. Klepper. "Time Paths in the Diffusion of Product Innovation." Economic Journal, 92 (1982), 630-653.

Guay, W., and S. Kothari. "How Much Do Firms Hedge with Derivatives?" Journal of Financial Economics, 80 (2003), 423-461.

Hackbarth, D., and D. C. Mauer. "Optimal Priority Structure, Capital Structure, and Investment." Review of Financial Studies, 25 (2012), 747-796.

Hadlock, C. J., and J. R. Pierce. "New Evidence on Measuring Financial Constraints: Moving Beyond the KZ Index." Review of Financial Studies, 23 (2010), 1909-1940.

Harford, J.; S. A. Mansi; and W. F. Maxwell. "Corporate Governance and Firm Cash Holdings in the US.” Journal of Financial Economics, 87 (2008), 535-555.

Hoberg, G.; G. Phillips; and N. Prabhala. "Product Market Threats, Payouts, and Financial Flexibility." Journal of Finance, 49 (2014), 293-324.

Imhoff, E. A., and G. J. Lobo. "The Effect of Ex Ante Earnings Uncertainty on Earnings Response Coefficients.” Accounting Review, 67 (1992), 427-439.

Jin, Y., and P. Jorion. "Firm Value and Hedging: Evidence from U.S. Oil and Gas Producers." Journal of Finance, 61 (2006), 893-919.

Johnson, T. C. "Forecast Dispersion and the Cross Section of Expected Returns." Journal of Finance, 59 (2004), 1957-1978.

Lang, L. H. P., and R. M. Stulz. "Tobin's Q, Corporate Diversification, and Firm Performance." Journal of Political Economy, 102 (1994), 1248-1280. 
Li, J. Y., and D. C. Mauer. "Financing Uncertain Growth.” Journal of Finance, 41 (2016), 241-261.

Mauer, D. C., and S. H. Ott. "Investment under Uncertainty: The Case of Replacement Investment Decisions." Journal of Financial and Quantitative Analysis, 30 (1995), 581-605.

Mauer, D. C., and S. H. Ott. "Agency Costs, Underinvestment, and Optimal Capital Structure: The Effect of Growth Options to Expand." In Project Flexibility, Agency, and Competition, M. J. Brennan and L. Trigeorgis, eds. New York, NY: Oxford University Press (2000), 151-180.

McDonald, R., and D. Siegel. "The Value of Waiting to Invest." Quarterly Journal of Economics, 101 (1986), 707-728.

Merton, R. C. "On the Pricing of Corporate Debt: The Risk Structure of Interest Rates." Journal of Finance, 29 (1974), 449-470.

Morellec, E., and N. Schürhoff. "Corporate Investment and Financing under Asymmetric Information.” Journal of Financial Economics, 99 (2011), 262-288.

Panousi, V., and D. Papanikolaou. "Investment, Idiosyncratic Risk, and Ownership." Journal of Finance, 67 (2012), 1113-1148.

Pástor, L., and P. Veronesi. "Stock Valuation and Learning about Profitability.” Journal of Finance, 58 (2003), 1749-1790.

Petersen, M. A. "Estimating Standard Errors in Finance Panel Data Sets: Comparing Approaches." Review of Financial Studies, 22 (2009), 435-480.

Rountree, B.; J. P. Weston; and G. Allayannis. "Do Investors Value Smooth Performance?" Journal of Financial Economics, 90 (2008), 237-251.

Schlingemann, F. P.; R. M. Stulz; and R. A. Walkling. "Divestitures and the Liquidity of the Market for Corporate Assets." Journal of Financial Economics, 64 (2002), 117-144.

Shleifer, A., and R. W. Vishny. "Liquidation Values and Debt Capacity: A Market Equilibrium Approach." Journal of Finance, 47 (1992), 1343-1366.

Spence, M. "Entry, Capacity, Investment, and Oligopolistic Pricing." Bell Journal of Economics, 8 (1977), 534-544.

Spence, M. "Investment Strategy and Growth in a New Market." Bell Journal of Economics, 10 (1979), $1-19$.

Warusawitharana, M. "Profitability and the Life Cycle of Firms." Working Paper, Board of Governors of the Federal Reserve System (2014).

Zhang, X. F. "Information Uncertainty and Stock Returns.” Journal of Finance, 61 (2006), 105-137. 